\title{
1 Transferability of predictive models of coral reef fish species
}

\section{2 richness}

3 Ana M. M. Sequeira ${ }^{1}$, Camille Mellin ${ }^{2,3}$, Hector M. Lozano-Montes ${ }^{4}$, Mathew A. Vanderklift ${ }^{4}$,

4 Russ C. Babcock ${ }^{4}$, Michael Haywood ${ }^{5}$, Jessica J. Meeuwig ${ }^{1}$, M. Julian Caley ${ }^{2}$

5

$6 \quad{ }^{1}$ UWA Oceans Institute and Centre for Marine Futures, University of Western Australia, School of

7 Animal Biology, University of Western Australia M470, 35 Stirling Highway, Crawley, Western

8 Australia 6009, Australia.

$9 \quad{ }^{2}$ Australian Institute of Marine Science, PMB No. 3, Townsville MC, Townsville, Queensland 4810,

10 Australia

$11{ }^{3}$ The Environment Institute and School of Earth and Environmental Sciences, The University of

12 Adelaide, South Australia 5005, Australia

$13{ }^{4}$ CSIRO, Oceans and Atmosphere Flagship, Underwood Avenue, Floreat, Western Australia 6014,

14 Australia.

$15{ }^{5}$ CSIRO, Marine and Atmospheric Research, Dutton Park, Brisbane, Queensland 4001, Australia.

17 Corresponding Author (ana.sequeira@uwa.edu.au)

18 Tel: +61(0)8 64882219

19

20 Running title: Transferability of biodiversity models

21 Word count: 7059: summary - 265; main text - 4520; acknowledgements - 52; references -

22 1146; tables - 779; figure legends - 276.

23 Tables: 3; Figures: 3; References: 43 


\section{Summary}

25 1. Understanding biodiversity patterns depends on data collection, which in marine environments can be prohibitively expensive. Transferable predictive models could therefore provide time- and cost-effective tools for understanding biodiversity environment relationships.

2. We used fish species counts and spatial and environmental predictors to develop predictive models of fish species richness $(S)$ for two major coral reefs located in separate ocean basins: Australia’s Great Barrier Reef (GBR; Queensland) and Ningaloo Reef (NR; Western Australia). We tested the ability of the GBR model to predict $S$ at NR (its transferability) under various scenarios using different sampling durations, years sampled and transect sizes.

3. Based on $\mathrm{R}^{2}$, the GBR model poorly predicted $S$ at $\mathrm{NR}\left(R^{2}<16 \%\right)$ with few predicted values strongly correlated with observations. However, comparable spatial patterns in $S$ across NR were predicted by both the NR and the GBR models when calibrated at similar spatio-temporal scales.

4. This result suggests that poor validation of the transferred models may indicate low deviance explained by the predictors in the new system (where other, not included, predictors might have a more direct effect on the response), and that in some situations, model transferability may be considerably improved by using datasets of similar spatiotemporal scales. Therefore, data filtering by time and space may be required prior to transferring models. 
5. Policy implications: Transferable models can provide initial estimates of fish species richness patterns in poorly sampled systems, and thereby guide the design of better and more efficient sampling programs. Further improvements in model transferability will increase their predictive power and utility in conservation planning and management.

KEYWORDS generalized linear mixed-effects modelling, Great Barrier Reef, Ningaloo Reef, prediction, spatial autocorrelation, biodiversity distribution models, macroecology.

\section{Introduction}

Anthropogenic impacts on global biodiversity are rapidly increasing (Worm et al. 2006), making the need for efficient management tools urgent. One option is to improve the predictive ability of biodiversity distribution models (a.k.a. species distribution, habitat suitability, resource selection and ecological niche models). Such models codify our understanding of relationships between biodiversity metrics (e.g., species occurrence, richness or abundance) and the environment, and are commonly used to predict spatial patterns of biodiversity in aid of conservation planning and management (Guisan \& Thuiller 2005). Following the surge of application of these models in terrestrial contexts (refer to Lehmann, Overton \& Austin 2002), they have now also been widely applied to marine environments (e.g., Kelly, Fonseca \& Whitfield 2001; Sequeira et al. 2014a), and specifically to coral reef systems (Mellin et al. 2010; Tittensor et al. 2010) where the influence of both fine- and broad-scale patterns of environmental variation (i.e., assumption of spatial stationarity) has also been tested (Mellin et al. 2010). A major strength of these models is their ability to predict species occurrence patterns in areas 
67 where no data are available (Robertson et al. 2003), whether by (i) interpolating results and

68 providing predictions for unsampled sites within the sampled area (e.g., Mellin et al. 2010), or by

69 (ii) forecasting results under expected future environments (Araújo \& New 2006; Sequeira et al.

70 2014a) or to new geographical areas (Sequeira et al. 2014a; Sequeira et al. 2014b), as defined by

71 Elith \& Leathwick (2009). The application of such models to unsampled areas is termed

72 transferability (Phillips 2008). Therefore, improving transferability of existing biodiversity

73 distribution models could provide cost-effective tools for understanding biodiversity-

74 environment relationships in support of conservation and management.

75 Previous studies of model transferability have focused largely on terrestrial ecosystems

76 (Graf et al. 2006; Randin et al. 2006), and have generated highly variable results ranging from

77 “zero” (Fielding \& Haworth 1995) to "highly accurate” transferability (Vanreusel, Maes \& Van

78 Dyck 2008). In aquatic environments, however, model transferability remains poorly studied,

79 having been examined for only a few anadromous and freshwater fish species (Sundblad et al.

80 2009; Wenger \& Olden 2012). Because geographical ranges of marine species are often larger

81 than those of terrestrial and freshwater species, marine systems may provide better possibilities

82 for building transferable biodiversity models as there will be more opportunities to fit models

83 using subsets of species' ranges, and testing their transferability to other parts of their ranges

84 (Robinson et al. 2011).

85 Among marine ecosystems, coral reefs are the most biodiverse and are globally

86 threatened (Knowlton et al. 2010; Plaisance et al. 2011). On coral reefs, biodiversity can be

87 predicted from a range of environmental factors, including depth, slope, sediment type, coastline

88 length or distances to shore or shelf, water temperature, chlorophyll $a$, and oxygen concentration

89 (e.g., Mellin et al. 2010; Tittensor et al. 2010). Of these, broad scale covariates are likely to be 
90 more appropriate for explaining variation at the ecosystem scale (Mellin et al. 2014).

91 Transferability of biodiversity models built around such broad-scale predictors could therefore

92 be particularly useful in assisting the management and conservation of coral reefs. Also, because

93 some coral reefs are relatively well sampled (Fisher et al. 2011), they present a good opportunity

94 to build predictive models of biodiversity patterns (e.g., Mellin et al. 2010) and then test their

95 transferability to other reef systems.

96 Here we begin the task of understanding how to improve transferability of predictive

97 models of fish species richness $(S)$ on coral reefs. We examine how well a model developed for a

98 well-studied reef system, the Great Barrier Reef (GBR), predicts $S$ at the ecologically distinct

99 and geographically distant Ningaloo Reef (NR), for which there is currently far less information

100 available (Fisher et al. 2011). We also tested whether transferability could be improved by using

101 different subsets of data (scenarios hereafter) during calibration of the GBR model, and then

102 compared each GBR scenario result with the results from an analogous predictive model

103 developed for NR using data collected at NR. From these comparisons, we identify key aspects

104 of predictive models that support transferability.

105 
107 The GBR, off NE Australia, is the world’s largest coral reef ecosystem ( 2300 km long, 60 to

$108250 \mathrm{~km}$ wide, 3000 individual reefs) (Fig. S1). NR, off NW Australia, is the world's largest

109 fringing reef ( $300 \mathrm{~km}$ long, $<3 \mathrm{~km}$ wide) (Fig. S1). These two fundamentally different reef

110 systems are separated by thousands of kilometres and are located in the Pacific and Indian Ocean

111 basins, respectively.

\section{Fish data}

113 We used reef fish data for the GBR from the Long Term Monitoring Program (Sweatman et al.

114 2008) of the Australian Institute of Marine Science (AIMS). A minimum of 137 sites from 46

115 reefs within six sectors of the GBR (Cooktown/Lizard Island, Cairns, Townsville, Whitsunday,

116 Swain, Capricorn Bunkers; Fig. S1) were surveyed during 2003-2005, and every second year

117 thereafter, until 2013. Species of the following ten fish families were counted: Acanthuridae,

118 Chaetodontidae, Labridae, Lethrinidae, Lutjanidae, Pomacentridae, Scaridae, Serranidae,

119 Siganidae, and Zanclidae (see Supporting Information species list). Counts were made using

120 5x50-m long transects per site across three shelf positions (inner, mid and outer) (for details, see

121 Halford \& Thompson 1996).

122 For NR, we used reef fish data from the Commonwealth Scientific and Industrial

123 Research Organisation (CSIRO) collected in 2013 (Fig. S1). A total of 88 sites were sampled

124 using 3x25-m long transects per site. Species from 46 families, including the 10 sampled on the

125 GBR, were counted. We modelled fish species richness $(S)$ for both the GBR and NR by pooling

$126 S$ across transects within sites, i.e., summing the total number of different species observed 
127 across transects sampled for each site. When data from multiple years were available for the

128 GBR, we also pooled $S$ across years within sites.

\section{Environmental and spatial predictors}

130 We used environmental data (see Table S1) with $0.01^{\circ}$ resolution, collated at a national scale

131 (Huang et al. 2010; www.marinehub.org) ensuring that environmental data used for both the

132 GBR and the NR were similar. This dataset (Table S1) includes bathymetric variables,

133 percentage cover of sediment characteristics such as carbonates, sand, gravel and mud, and

134 averaged mean annual estimates and seasonal ranges for nutrients (nitrate, silicate, phosphate),

135 oxygen, salinity, temperature and chlorophyll $a$. Because the 'annual mean estimates' and

136 'seasonal ranges' of the variables were mostly correlated, we only used 'annual mean estimates'

137 (Table S1). For NR, we also used hyperspectral bathymetric data (Heyward 2006).

138 We assigned to each fish sampling site the environmental values on for the closest grid-

139 cell, and calculated the spatial predictors shortest distance to coast (coast) and to the outer limit

140 of the reefs (barrier). We calculated these distances using the Near tool in ArcGIS10.1 (ESRI,

141 Redlands, CA) and the Equidistant Cylindrical projection from the spherical geographical

142 coordinate system.

143 We selected our models predictors according to their multicollinearity estimated by

144 Spearman's correlation coefficient $(\rho)$ from the pairs . panels function from the psych

145 package in R (R Core Team 2014). Our final model set (Table 1) considered different categories

146 of predictors in different models, and by including only non-collinear variables (i.e., $\rho<0.5$ )

147 within each model in the model set. To account for non-linear dependencies with bathymetry,

148 distances to domain boundaries and sea surface temperature, we included the respective 
149 predictors (depth, coast and barrier, and SSTav) as a second order polynomial using the poly

150 function from the stats package in R. This was done after comparing models including the

151 quadratic terms and models including only the linear term for each predictor.

\section{Modelling approach}

153 Our modelling approach is summarised in Fig. 1. After predictor selection, we developed two

154 NR models for $S$ (hereafter NR models) using: (i) species data from the ten families sampled on 155 the GBR $\left(S_{10}\right)$ and (ii) all species data collected at NR $\left(S_{\text {All }}\right)$.

$156 \quad$ For the GBR, we used different data subsets for developing a set of modelling scenarios

157 (i.e., scenarios A to G; Table 2) to explore the influence of different calibration datasets on

158 model transferability. Scenario A was based on Mellin et al (2010), where spatial patterns of fish

159 species richness was successfully predicted using four years of data (2003 - 2007, except 2006)

160 collected using $50 \mathrm{~m}$ transects and a similar environmental dataset (Appendix S1, Table S2, Fig.

161 S2). We then built the other scenarios (i.e., B-G) using updated environmental data, with

162 scenario B repeating scenario A but using these updated data. For the remaining scenarios we

163 changed the (i) sampling years to cover four years of data collected more recently (2007 - 2013

164 odd years only; scenario C), (ii) transect size to $25 \mathrm{~m}$ (scenario D), and (iii) length of the dataset

165 used to a single year: 2007 for scenarios E and F, and 2013 for scenario G, where downscaling

166 was also tested in F and G (Table 2). We downscaled the GBR transect data (length $=50 \mathrm{~m}$ ) to

167 match the transect size sampled at NR (length $=25 \mathrm{~m}$ ) by: (i) calculating the average increase in

168 the number of species added per transect (50-m long) within each site (first transect selected

169 randomly, and iterated 100 times) to account for differences in $S$ among sites, then (ii) dividing 
170 the resulting average by 2 (the ratio between 50 and $25 \mathrm{~m}$ ), and then (iii) subtracting this amount

171 from the totals observed on each transect within the same site on the GBR.

172 We started by developing generalized linear models (GLM) using a Poisson distribution

173 and log link function, following Mellin et al. (2010). We then calculated Moran’s I (Diggle \&

174 Ribeiro 2007) to test for spatial autocorrelation in model residuals using the $s p$.correlogram

175 function from the spdep library (Bivand 2013) in R. If significant spatial autocorrelation was

176 present, we developed generalised linear mixed-effects models (GLMM) by including a spatial

177 random effect for reef to account for relationships among sites within each reef. We did this

178 using the lmer function from the lme4 package in R (Bates et al. 2013). For model assessment,

179 we used Akaike’s (corrected for small sample sizes; $\mathrm{AIC}_{c}$ ) and the Bayesian (BIC) information

180 criteria (Burnham \& Anderson 2004) and their weights (wAICc, wBIC, respectively) to (i)

181 compare model probabilities, and to (ii) assess each model's strength of evidence relative to the

182 entire model set. To assess the model's goodness-of-fit and draw comparisons between models

183 from the same model set, we used the percentage of deviance explained (\%De; a pseudo- $\mathrm{R}^{2}$

184 referring to a likelihood ratio between each model and the null model) for GLM, and the

185 marginal and conditional $\mathrm{R}^{2}$ (Nakagawa \& Schielzeth 2013) for GLMM. We first used each

186 model to predict $S$ in the respective reef system, and validated the results by calculating the mean

187 10-fold cross-validation error (Davison \& Hinkley 1997) for each model and across the model

188 set. We validated our predicted patterns of $S$ for NR by examining the correlation between the

189 observed and predicted values on sampled sites when developing a linear model (LM) using field

190 observations as the response and the corresponding $S$ predictions as predictor (Piñeiro et al.

191 2008). We then compared the goodness-of-fit of these LM models using the resulting $p$-values

192 and $\mathrm{R}^{2}$. We also calculated mean effect sizes for each predictor following Sequeira et al (2014b). 


\section{Testing model transferability}

194 Because the GBR is a diverse reef system, the calibration of the GBR models includes a series of

195 different habitats and/or reef regions (sensu Graf et al. 2006) potentially allowing estimation of a

196 more general relationship between $S$ and the environmental variables considered, which might

197 also be transferable to other reef ecosystems (sensu Vanreusel, Maes \& Van Dyck 2008; Wenger

198 \& Olden 2012). The NR model, on the other hand, was calibrated using comparatively limited

199 data specific to NR's ecological and biogeographical settings. Therefore, we tested model

200 transferability from the GBR to NR by predicting $S$ patterns at NR using the GBR models, but

201 not the reverse.

202 To test the influence of different calibration datasets on model transferability (Fielding \&

203 Haworth 1995), we used each model scenario for the GBR to predict $S$ at NR and then assessed

204 transferability in two ways (Fig. 1). First, we validated our cross-system predictions with data

205 collected at NR. We did this by comparing the goodness-of-fit (i.e., $\mathrm{R}^{2}$ and $p$-values) of a LM of

206 the $S$ predictions for NR from each GBR scenario as a function of the observed values at NR.

207 When transferred models from the GBR failed to predict low $S$ ( $<30$ species), we also tested the

208 LM using only locations at NR where > 30 species were observed. Second, we compared the

209 results from our GBR scenarios predicting to NR and those from the NR(S $\left.S_{10}\right)$ model by

210 calculating differences in estimated means, and by comparing maps of predicted $S$ for NR by

211 both the GBR scenarios (i.e., transferred models) and the $\mathrm{NR}\left(S_{10}\right)$ model. We did the latter in

212 four ways: (i) we compared the mean direct validation errors (observed versus predicted values

213 from LM) obtained for both procedures to estimate differences in accuracy by both models ; (ii)

214 we calculated the mean absolute difference between values predicted by both models on a grid-

215 cell basis to compare the precision of the resulting predictions; (iii) we estimated the percentage 
216 of grid-cells with absolute values differing $\leq 15 \%$ (i.e., by $\leq 5.4 \pm 0.9$ species) between both

217 models to quantify how comparable both predictions were; and finally, (iv) we rescaled the

218 predictions from the GBR scenarios to the same maximum and minimum value of $S$ predicted by

219 the NR(S10) model to directly compare the high-versus-low $S$ patterns predicted for NR by both 220 procedures.

222 Results

223 Our model set, including 17 environmental predictors, was similar for both reef ecosystems

224 (Table 1). Occasional differences (models 1 and 4; Table 1) were needed to avoid strong

225 collinearity between variables (Spearman's $\rho>0.5$ ) observed at NR, but not for the GBR. We

226 also observed little spatial autocorrelation in the residuals of the NR models (first lag only and

227 Moran’s I < 0.2). Therefore, we modelled $S$ at NR using GLM. For both NR models $\left(S_{\text {All }}\right.$ and

$228 S_{10}$ ), the full model (model 1) explained the greatest deviance (23.6 \% and $27.8 \%$, respectively)

229 in $S$, while the 'nutrient' model (model 7) had the strongest support (wAICc $=0.984$ and 0.953,

230 respectively; $w \mathrm{BIC}=1$ for both models). Model 7 also had the lowest cross validation error in

231 both NR models ( $8.8 \pm 2.7$ and $7.6 \pm 2.3$ species, respectively). The predictors with greatest

232 effect size were: nitrate (NO3av) and oxygen concentration (O2av) followed by chlorophyll $a$

233 (Chla) and the coefficient of light attenuation (K490) (Fig. S3 - NR). The NR model-averaged

234 predictions of $S$ were correlated with the observed values $\left(\mathrm{R}^{2}=0.396\right.$ and 0.437 for $S_{\text {All }}$ and $S_{10}$,

235 respectively, $p<0.001$; Fig. S4). The models predicted higher $S$ in the northern central sections

236 of NR, and lower $S$ in the south and northernmost sections of NR (Fig. 2a). 
For most GBR scenarios (A - E, except B) the light attenuation model (model 11)

238 received the strongest $w \mathrm{AIC}_{c}$ and $w \mathrm{BIC}$ support. For scenarios $\mathrm{F}$ and $\mathrm{G}$, a different set of two

239 models received equally high AIC $_{c}$ (model 11 and 4, and model 10 and 1, respectively; Table

240 S3). Scenario F had the lowest cross-validation error (7.8 \pm 1.5 species), and scenario $G$ had the

241 highest $\mathrm{R}^{2}$ (31.6 and 57. 5, respectively for model 10 and 1$)$ and $\mathrm{R}^{2} \mathrm{~m}$ (83.0 and 83.85,

242 respectively for model 10 and 1) (Table S3). Both scenarios F and G used GBR data downscaled

243 to $25 \mathrm{~m}$ from one year only (2007 and 2013, respectively) (Table 2). The predictors with greatest

244 effect sizes were similar for all GBR scenarios (Fig. S3), except scenario G for which salinity

245 had the largest effect size, and the effect of some other predictors was also closer to that obtained

246 for the NR model (e.g., quadratic terms for coast and SSTav) (Fig. S3). The predicted patterns of

$247 S$ for the GBR were also similar for all GBR scenarios (Fig. 2b) however, the predicted range

248 was always narrower than the observed values (cf Tables 2 and 3).

249 For GBR scenarios transferred to NR, the range of predicted $S$ (Table 3) was also always

250 narrower than the observed range at NR (8 - 67 species). The transferred GBR models failed to

251 predict observed values $<30$ species resulting in weaker correlations between the predictions

252 from the GBR scenarios and NR observations $\left(\mathrm{R}^{2}<20.7 \%\right)$ (Table 3). $\mathrm{R}^{2}$ was lowest for

253 scenarios F and G ( $p>0.05)$ despite the range of $S$ predicted by scenario G (32.2 - 53.3 species)

254 being the closest to that observed at NR. To confirm that poor validation was associated with

255 lack of prediction for $S<30$, we validated these two scenarios using LM at locations at NR

256 where $>30$ species were observed. This restriction resulted in a higher $\mathrm{R}^{2}$ for scenario $\mathrm{G}$ (13.1

$257 \% ; p<0.05$ ) (Table 3). The mean predicted estimates of $S$ for NR by the transferred GBR

258 scenarios were also greater than those predicted by the NR models, except for scenarios E, F and

259 G, which included GBR data from one year only (i.e., similar to NR data). Similar results were 
260 obtained for the direct validation error, which was generally high for most scenarios ( $40 \%$;

261 Table 3), but again, lower for scenarios E, F and G ( $<28 \%)$. The prediction maps for NR from

262 the GBR scenarios A - D mostly over-predicted $S$ for all NR locations (Fig. 3a). Prediction maps

263 from scenarios $\mathrm{F}$ and $\mathrm{G}$ resulted in the lowest absolute mean differences (8.2 \pm 7.9 and $6.1 \pm 6.7$

264 species, respectively; Table 3), and highest $\%$ of the grid-cells with predicted $S$ differing $\leq 15 \%$

265 (i.e., $\leq 5.4 \pm 0.9$ species; Table 3 ) to that predicted by the NR model. When comparing the high-

266 versus-low $S$ patterns predicted for NR by the transferred GBR scenarios, predictions from

267 scenario G were the most similar ( $35 \%$ replicated) to those obtained by the NR model (Fig.

268 3b). Differences in the maps obtained by the GBR scenario G and the NR model included greater

269 than expected $S$ predicted around Mangrove Reef, in the northernmost section of NR, and in the

270 Cloates area, higher $S$ was predicted only towards the reef but not in the lagoon (Fig. 3c).

271 Predictions from the transferred GBR scenarios E, F and G (one year of GBR data) were

272 most comparable to those obtained from the NR model (Table 3). Among these, predictions from

273 scenario F (2007 data, downscaled to $25 \mathrm{~m}$ ) resulted in a lower mean absolute difference

274 compared to those from the NR model (6.1 \pm 6.7 species) and the highest \% grid-cells with

275 predicted $S$ values differing $\leq 15 \%$ from the predictions obtained with the NR models. Scenario

276 G, however, calibrated with downscaled GBR data collected in the same year (2013) as the data

277 from NR, resulted in the most comparable high-versus-low patterns predicted (Fig. 3c).

278

279 Discussion

280 Transferability is an important utility of ecological models for conservation planning and

281 management (Murray et al. 2011), but what confers transferability upon these models remain 
282 poorly understood. To help address this knowledge gap, we tested the transferability of $S$ models

283 between two fundamentally different reef ecosystems located in separate ocean basins, and

284 demonstrate that comparable patterns of $S$ can be predicted either by applying a model developed

285 for the GBR to NR, or by developing a new model calibrated for NR. Our results suggest that

286 both data and models developed for a well-studied reef ecosystem (e.g., GBR) can provide useful

287 information for understanding other coral reefs. Further research is needed, however, to improve 288 model transferability.

289 Transferability of our GBR models was better when the spatio-temporal scales of the 290 calibration data matched the scales of the data observed in the other reef system (NR). This 291 included matched (i) temporal range (one year only), (ii) sampling year (same year for both 292 systems), and (iii) transect size. Consistent with Fielding and Haworth (1995), our results from 293 transferring each GBR scenario supports the idea that model transferability is affected by the 294 data used to develop the model to be transferred. During model development, we also adopted 295 existing recommendations for improving transferability, including the use of GLMs, which may 296 be better suited for transferability than e.g., GAMs due to data overfitting (Randin et al. 2006). 297 We also developed models with non-site specific predictors (Fielding \& Haworth 1995; Graf et 298 al. 2006; Vanreusel, Maes \& Van Dyck 2008; Heinänen, Erola \& von Numers 2012) by using 299 environmental variables available for both reefs and by testing transferability from a diverse 300 system with different habitat types and/or reef regions (GBR) to a fringing reef system (NR). The 301 vastness of the GBR also allowed the GBR model to incorporate a large range of predictor values 302 mostly encompassing those observed for NR, which is essential for reducing extrapolation when 303 predicting to a new location (Thuiller et al. 2004; Randin et al. 2006; Sundblad et al. 2009). The 
304 more extensive data from the GBR also likely facilitated better estimation of relationships

305 between $S$ and the environmental variables considered.

306 For both NR models ( $S_{10}$ and $S_{\text {All }}$ ), environmental predictors explained relatively little

307 deviance in observed $S$ ( $<28 \%)$. Therefore, we expected a low $\mathrm{R}^{2}(<20.7 \%)$ using LM to

308 compare predictions from the GBR scenarios with those from NR indicating poor model

309 transferability. Indeed, direct validation showed poor transferability for scenario $\mathrm{G}\left(\mathrm{R}^{2} \sim 2 \%, p\right.$

$310>0.05)$ even though the most similar patterns of $S$ were predicted by this scenario and by the NR

311 model (Fig. 3). We attribute this result mostly to the lack of predictions $<30$ species; our LM for

312 observations of $>30$ species resulted in a significant $\mathrm{R}^{2}$ of $13.1 \%$. The general over-prediction

313 of $S$ at NR by the GBR models may stem from differences among sampled sites at both reefs.

314 GBR sampling included locations with greater coral cover (Sweatman et al. 2008) than those at

315 NR, which were mostly on reef flats where lower fish density is expected (Gratwicke \& Speight

316 2005). Direct validation of the NR model predictions resulted in $\mathrm{R}^{2}$ values of $\sim 40 \%$, which

317 were slightly higher than the highest deviance explained by the NR models ( $<28 \%$, Table S3).

318 These results suggest that poor direct validation of transferred models may be indicative of low

319 deviance explained by the predictors in the new system rather than poor model transferability per

320 se. If so, the environmental predictors in our models might only be reflecting indirect effects on $S$

321 patterns in NR while other factors not accounted for, such as system-specific constraints like

322 fishing pressure, may be influencing the number species observed per unit area (Vanderklift,

323 Babcock \& Cook 2013). As fishing pressure is typically species and size selective (Zhou et al.

324 2010), differential fishing pressure among locations may condition relationships between

325 environmental predictors by changing species abundance distributions. Accounting for 
differences in fishing pressure among reefs where predictive models are built and those to which

327 they are transferred may help improve our understanding of model transferability.

329 information criteria, importance of predictors, and general spatial patterns of $S$ on the GBR (Fig.

330 2b), indicating that models developed for the GBR are potentially stable and robust even when

331 using shorter time series. For scenarios F and G, the results were the most dissimilar, with effect

332 sizes of some predictors becoming more comparable to those obtained with the NR model.

333 Differences in effect sizes, and the importance of predictors have previously been associated

334 with different discriminative ability of transferred models (Murray et al. 2011). Therefore, the

335 effect size changes of some predictors for scenario G might have contributed to the similarities in

336 the resulting high-versus-low spatial patterns of $S$ predicted for NR by this scenario and those

337 from the NR model. As observed for model transferability in terrestrial ecosystems (Heinänen,

338 Erola \& von Numers 2012), our results focused on fish species richness also suggest that the

339 most transferable model might not be the most robust model for the reef system from which it is

340 transferred.

341 When comparing the predicted patterns of $S$ for the GBR from the GBR scenarios F and

342 G (Fig. 2b) which used GBR data from 2007 and 2013, respectively, the map for the more recent

343 scenario shows a slightly reduced area of higher $S$ and higher prediction uncertainty. Such

344 change in predicted patterns indicates that other factors not accounted for in the models may be

345 influencing $S$ patterns on the GBR as well, possibly reducing species richness. When transferred

346 to NR, GBR Scenario G was the only one not to predict high $S$ in the southern sections of NR

347 (Fig. 3b) and therefore predicted the most comparable $S$ patterns at NR (Fig. 3c). However, GBR

348 scenario G predicted higher $S$ in the northernmost sections of NR (around Mangrove) as well, 
349 where more shore-based recreational activities (including fishing) occur year round (Smallwood

350 et al. 2011). Similarly to the NR model, the GBR scenario G also predicted slightly higher $S$

351 between Point Cloates and Coral Bay but only towards the reef and not in the lagoon. This

352 difference in predictions may be associated with non-stationarity or simply with differences in

353 the way data were collected in each reef ecosystem as highlighted above. The downscaling

354 procedure used to match the GBR and NR data also had a large effect on predictions (cf E and F,

355 both calibrated with data from 2007, Table 3). While validation error and high-versus-low

356 patterns obtained by scenarios $\mathrm{D}$ and $\mathrm{F}$ are similar, the downscaling procedure used in scenario $\mathrm{F}$

357 greatly reduced absolute mean difference in predicted values from $11.9 \pm 7.2$ to $6.1 \pm 6.7$

358 species, and increased by $40 \%$ the percentage of grid-cells with predicted $S$ differing $\leq 15 \%$ from

359 the predictions of the NR model. The high-versus-low patterns most comparable to those

360 obtained from the NR model were, however, obtained for the transferred GBR scenario G which

361 used data from the same year as the observations at NR. This result suggests a temporal

362 association between patterns of $S$ between reef ecosystems separated by thousands of kilometres.

363 Potential causes of such synchrony are not yet understood but may be worth pursuing in future

364 research.

365 While we suggest here a path for improving model transferability, better understanding is

366 still required about how to maximize and assess it, and about how inter-reef differences may

367 affect transferability. In summary, to assist in understanding what confers transferability to

368 biodiversity models, we suggest that (i) data of the same spatio-temporal range, (ii) general

369 environmental predictors, and (iii) models that do not over fit data be used. Where some data

370 from the system to which the model is transferred exists, comparison of model results will be

371 enhanced. We also suggest that other modelling frameworks, such as Bayesian approaches that 
372 can make use of prior information, be tested in a model transferability context. Our work

373 illustrates initial steps towards improved model transferability among coral reefs, and

374 demonstrates that transferred models can provide useful information even for fundamentally

375 different and geographically distant reef systems. The more model transferability can be

376 improved, the more useful will these tools be for conservation and management.

377

378 Acknowledgments

379 AMMS was funded by UWA, AIMS and CSIRO, through an Indian Ocean Marine Research

380 Centre (IOMRC) Postdoctoral Fellowship. CM was funded by the Marine Biodiversity Hub

381 (www.nerpmarine.edu.au) and by ARC Grant (DE140100701). Thanks to R Pitcher and M Case

382 for access to environmental data, and to all collectors of the fish data.

383 


\section{References}

385 Araújo, M.B. \& New, M. (2006) Ensemble forecasting of species distributions. Trends in Ecology and Evolution, 22, 42-47.

387 Bates, D., Maechler, M., Bolker, B. \& Walker, S. (2013) lme4: linear mixed-effects models using Eigen and S4. R package version 1.0-4. http://CRAN.R-project.org/package=lme4.

Bivand, R. (2013) spdep: spatial dependence: weighting schemes, statistics and models. R package version 0.5-65. http://CRAN.R-project.org/package=spdep.

391 Burnham, K.P. \& Anderson, D.R. (2004) Multimodel inference: understanding AIC and BIC in model selection. Sociological Methods \& Research, 33, 261-304.

Davison, A.C. \& Hinkley, D.V. (1997) Bootstrap methods and their application. Cambridge University Press, New York, NY, USA

Diggle, P. \& Ribeiro, P.J. (2007) Model-based geostatistics Springer, New York.

Elith, J. \& Leathwick, J.R. (2009) Species distribution models: ecological explanation and prediction across space and time. Annual Review of Ecology, Evolution and Systematics, 40, 677-697.

Fielding, A.H. \& Haworth, P.F. (1995) Testing the generality of bird-habitat models. Conservation Biology, 9, 1466-1481.

Fisher, R., Radford, B.T., Knowlton, N., Brainard, R.E., Michaelis, F.B. \& Caley, M.J. (2011) Global mismatch between research effort and conservation needs of tropical coral reefs. Conservation Letters, 4, 64-72. 
404 Graf, R.F., Bollmann, K., Sachot, S., Suter, W. \& Bugmann, H. (2006) On the generality of

405 habitat distribution models: a case study of capercaillie in three swiss regions.

$406 \quad$ Ecography, 29, 319-328.

407 Gratwicke, B. \& Speight, M.R. (2005) The relationship between fish species richness, abundance 408 and habitat complexity in a range of shallow tropical marine habitats. Journal of Fish 409 Biology, 66, 650-667.

410 Guisan, A. \& Thuiller, W. (2005) Predicting species distribution: offering more than simple 411 habitat models. Ecology Letters, 8, 993-1009.

412 Halford, A.R. \& Thompson, A.A. (1996) Visual census surveys of reef fish. Long-term monitoring of the Great Barrier Reef. Standard Operational Procedure Number 3. Australian Institute of Marine Science, Townsville, Australia.

Heinänen, S., Erola, J. \& von Numers, M. (2012) High resolution species distribution models of two nesting water bird species: a study of transferability and predictive performance.

Heyward, A.J. (2006) Hyperspectral surveys of Ningaloo Marine Park, Western Australia. Survey contracted by the Australian Institute of Marine Sciences to HyVista Corporation with financial support from BHP Billiton Petroleum, Ltd, www.aims.gov.au.

421 Huang, Z., Brooke, B., Whitta, N., Potter, A., Fuller, M., Dunn, J. \& Pitcher, R. (2010) Australian Marine Physical Environmental Data - Descriptions and Metadata. Record 2010/32, pp. 141. Geoscience Australia 
425

426

427

428

429

430

431

432

433

434

435

436

437

438

439

440

441

442

443

444

445

446

447

Kelly, N.M., Fonseca, M. \& Whitfield, P. (2001) Predictive mapping for management and conservation of seagrass beds in North Carolina. Aquatic conservation: Marine and Freshwater ecosystems, 11, 437-451.

Knowlton, N., Brainard, R.E., Fisher, R., Moews, M., Plaisance, L. \& Caley, M.J. (2010) Coral reef biodiversity. Life in the World's Oceans (ed. A.D. McIntyre), pp. 65-77.

Lehmann, A., Overton, J.M. \& Austin, M.P. (2002) Regression models for spatial prediction: their role for biodiversity and conservation. Biodiversity and conservation, 11, 20852092.

Mellin, C., Bradshaw, C.J.A., Meekan, M.G. \& Caley, M.J. (2010) Environmental and spatial predictors of species richness and abundance in coral reef fishes. Global Ecology and Biogeography, 19, 212-222.

Mellin, C., Mengersen, K., Bradshaw, C.J.A. \& Caley, M.J. (2014) Generalizing the use of geographical weights in biodiversity modelling. Global Ecology and Biogeography, 23, $1314-1323$.

Murray, J.V., Choy, S.L., McAlpin, C.A., Possingham, H.P. \& Goldizen, A.W. (2011) Evaluating model transferability for a threatened species to adjacent areas: implications for rock-wallaby conservation. Austral Ecology, 36, 76-89.

Nakagawa, S. \& Schielzeth, H. (2013) A general and simplemethod for obtaining R2 from generalized linearmixed-effects models. Methods in Ecology and Evolution, 4, 133-142.

Phillips, S.J. (2008) Transferability, sample selection bias and background data in presence-only modelling: a response to Peterson et al. (2007). Ecography, 31, 272-278.

Piñeiro, G., Perelman, S., Guerschman, J.P. \& Paruelo, J.M. (2008) How to evaluate models: observed vs. predicted or predicted vs. observed? Ecological Modelling, 216, 316-322. 
Plaisance, L., Caley, M.J., Brainard, R.E. \& Knowlton, N. (2011) The diversity of coral reefs: what are we missing? PLoS ONE, 6, e25026.

R Core Team (2014) R: A language and environment for statistical computing. R Foundation for Statistical Computing; Vienna, Austria. ISBN 3-900051-07-0, URL http://www.Rproject.org/.

Randin, C.F., Dirnböck, T., Dullinger, S., Zimmermann, N.E., Zappa, M. \& Guisan, A. (2006) Are niche-based species distribution models transferable in space? Journal of Biogeography, 33, 1689-1703.

Robertson, M.P., Peter, C.I., Villet, M.H. \& Ripley, B.S. (2003) Comparing models for predicting species’ potential distributions: a case study using correlative and mechanistic predictive modelling techniques. Ecological Modelling, 164, 153-167.

Robinson, L.M., Elith, J., Hobday, A.J., Pearson, R.G., Kendall, B.E., Possingham, H.P. \& Richardson, A.J. (2011) Pushing the limits in marine species distribution modelling: lessons from the land present challenges and opportunities. Global Ecology and Biogeography, 20, 7889-7802.

Sequeira, A.M.M., Mellin, C., Fordham, D.A., Meekan, M.G. \& Bradshaw, C.J.A. (2014a) Predicting current and future global distributions of whale sharks. Global Change Biology, 20, 778-789.

Sequeira, A.M.M., Roetman, P.E.J., Daniels, C.B., Baker, A.K. \& Bradshaw, C.J.A. (2014b) Distribution models for koalas in South Australia using citizen science-collected data. Ecology and Evolution, doi: 10.1002/ece3.1094, 12. 
Smallwood, C.B., Beckley, L.E., Moore, S.A. \& Kobryn, H.T. (2011) Assessing patterns of recreational use in large marine parks: A case study from Ningaloo Marine Park, Australia. Ocean \& Coastal Management, 54, 330-340.

Sundblad, G., Härmä, M., Lappalainen, A., Urho, L. \& Bergström, U. (2009) Transferability of predictive fish distribution models in two coastal systems. Estuarine, Coastal and Shelf Science, 83, 90-96.

Sweatman, H., Cheal, A., Coleman, C., Emslie, M., Johns, K., Jonker, M., Miller, I. \& Osborne, K. (2008) Long-term monitoring of the Great Barrier Reef. Status Report No. 8. Australian Institute of Marine Science, Townsville, Queensland, Australia.

Thuiller, W., Brotons, L., Araújo, M.B. \& Lavorel, S. (2004) Effects of restricting environmental range of data to project current and future species distributions. Ecography, 27, 165-172.

Tittensor, D.P., Mora, C., Jetz, W., Lotze, H.K., Ricard, D., Berghe, E.V. \& Worm, B. (2010) Global patterns and predictors of marine biodiversity across taxa. Nature, 466, 10981104.

Vanderklift, M.A., Babcock, R.C. \& Cook, K. (2013) The effects of protection from fishing on species richness: distinguishing between alternative explanations. Oecologia, 171, 309315.

Vanreusel, W., Maes, D. \& Van Dyck, H. (2008) Transferability of species distribution models: a functional habitat approach for two regionally threatened butterflies. Conservation Biology, 21, 201-212.

Venables, W.N. \& Ripley, B.D. (2002) Modern Applied Statistics with S. Springer, New york. 
490 Wenger, S.J. \& Olden, J.D. (2012) Assessing transferability of ecological models: an

491 underappreciated aspect of statistical validation. Methods in Ecology and Evolution, 3,

$492 \quad 260-267$.

493 Worm, B., Barbier, E.B., Beaumont, N., Duffy, J.E., Folke, C., Halpern, B.S., Jackson, J.B.C.,

494 Lotze, H.K., Micheli, F., Palumbi, S.R., Sala, E., Selkoe, K.A., Stachowicz, J.J. \&

495 Watson, R. (2006) Impacts of biodiversity loss on ocean ecosystem services. Science,

$496 \quad 314,787-790$.

497 Zhou, S., Smith, A.D.M., Puntm, A.E., Richardson, A.J., Gibbs, M., Fulton, E.A., Pascoe, S.,

498 Bulman, C., Bayliss, P. \& Sainsbury, K. (2010) Ecosystem-based fisheries management

499 requires a change to the selective fishing philosophy. Proceedings of the National

$500 \quad$ Academy of Sciences, 107, 9485-9489.

501 
502 Tables

\section{Table 1}

504 Models relating coral reef fish species richness (S) to environmental factors of the Great Barrier Reef (GBR) and Ningaloo Reef (NR).

505 Coast: distance to coast; barrier: distance to the reef's outer limit; crbnt: percent carbonates; percent gravel, sand, and mud;

506 concentrations of NO3: nitrate, PO4: phosphate, SI: silicate, O2: dissolved oxygen, Chla: chlorophyll $a$; Sal: salinity; SST: annual sea

507 surface temperature; K490: coefficient of light attenuation at $490 \mathrm{~nm}$; subscript av: average. All predictors were mean centred, and

508 coast, barrier, depth, and SST $T_{a v}$ were included as quadratic terms. Sediment variables were mostly collinear and therefore were

509 included in separate models (4 - 6). Bold face indicates predictors not included in both systems due to collinearity between variables

510 observed at NR. 


\begin{tabular}{|c|c|c|}
\hline Model & Predictor category & GBR model \\
\hline 1 & Full model & 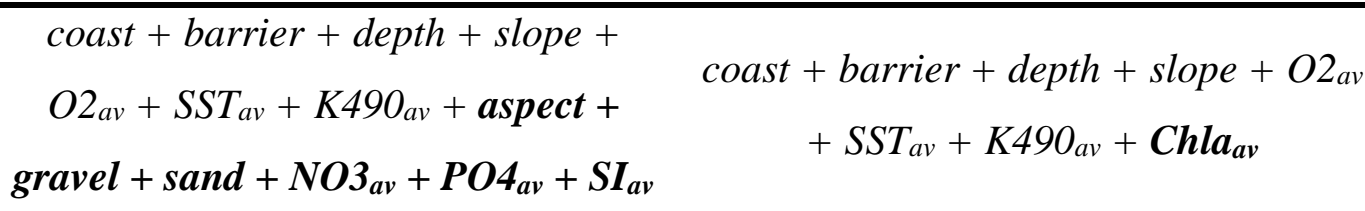 \\
\hline 2 & Distance to domain boundaries & coast + barrier \\
\hline 3 & Physical predictors including range of depths & depth + aspect + slope \\
\hline 4 & Sediment characteristics & crbnt + gravel \\
\hline 5 & Sediment characteristics & sand \\
\hline 6 & Sediment characteristics & mud \\
\hline 7 & Nutrients & $\mathrm{NO3}_{a v}+\mathrm{PO}_{a v}+\mathrm{SI}_{a v}$ \\
\hline 8 & Oxygen and salinity & O2av + Salav \\
\hline 9 & Productivity & Chla $a v$ \\
\hline 10 & Temperature & $S S T_{a v}$ \\
\hline 11 & Light availability & K490av \\
\hline 12 & Null model & 1 \\
\hline
\end{tabular}

511 
513 Data included in each Great Barrier Reef (GBR) modelling scenario. Temporal range:

514 sampling year (odd years only after 2005); sources of environmental data: NERP (National

515 Environment Research Program) updated from CERF (Commonwealth of Australia's

516 Environment Research Facility); $S$ range: species richness observed per site averaged across

517 transects. Scenario A is reproduced from Mellin et al. (2010) (details in Appendix 1).

$518 *$ denotes downscaled transect size (see Methods for details).

\begin{tabular}{ccccc}
\hline Scenario & Temporal & Environmental & & Transect \\
& range & data & & length $(\mathrm{m}) *$ \\
A & $2003-2007$ & CERF & $32-100$ & 50 \\
B & $2003-2007$ & NERP & $32-100$ & 50 \\
C & $2007-2013$ & NERP & $32-107$ & 50 \\
D & $2007-2013$ & NERP & $32-102$ & $25^{*}$ \\
E & 2007 & NERP & $9-73$ & 50 \\
F & 2007 & NERP & $8-66$ & $25^{*}$ \\
G & 2013 & NERP & $5-80$ & $25^{*}$ \\
\hline
\end{tabular}


520 Model-averaged predictions of fish species richness $(S)$ for Ningaloo Reef (NR) and the Great Barrier Reef (GBR). Results are for the NR model using all species sampled ( $S_{\text {All }}$ ), and only the species from the 10 families sampled on the GBR $\left(S_{10}\right)$, and for the GBR scenarios A to G (see Table 2 for description). $\mathrm{R}^{2}$ and $p$-value: results from linear models using prediction results as a function of the observed values at NR (* indicates p-values $<0.05)$. Valerror: validation error from comparing predictions with values observed at NR. Abs diff from $S_{10}$ : the absolute mean differences between the predicted $S$ from each GBR scenario and $S_{10}$ (also shown in percentage). \% grid-cell $\leq 15 \%$ : the percentage of grid-cells from the GBR scenario predictions differing only $\leq 15 \%$ (i.e., $5.4 \pm 0.9$ species) from those obtained with $\mathrm{S}_{10}$ within the same gridcells. High-versus-low: the percentage of grid-cells from the GBR scenarios predicting relative high-versus-low $S$ in NR similar to the

527 predictions obtained from $\mathrm{S}_{10}$. Observed $S$ range at NR was $8-74$ species. Italic font show results considering only observed $S>30$ (applicable 528 to scenarios F and G only).

\begin{tabular}{|c|c|c|c|c|c|c|c|c|c|}
\hline & & \multirow{2}{*}{$\begin{array}{c}\text { Predicted } S \\
\text { range }\end{array}$} & \multicolumn{2}{|c|}{ Direct validation } & \multicolumn{5}{|c|}{ Prediction results } \\
\hline & & & $\mathrm{R}^{2}$ & p-value & $\begin{array}{c}\text { Mean } S \\
\text { predicted }\end{array}$ & Valerror & $\begin{array}{l}\text { Abs diff } \\
\text { from } S_{10}\end{array}$ & $\begin{array}{c}\text { \% grid-cell } \\
\leq 15 \%\end{array}$ & $\begin{array}{c}\text { high-versus- } \\
\text { low (\%) }\end{array}$ \\
\hline \multirow[t]{2}{*}{ NR } & $S_{\text {All }}$ & $6.7-55$ & 39.6 & $<0.001$ & 42 & $\begin{array}{c}7.3 \pm 5.6 \\
(17.8 \pm 13.9 \%)\end{array}$ & - & - & - \\
\hline & $S_{10}$ & $4.7-47.8$ & 43.7 & $<0.001$ & 36 & $8.5 \pm 2.2$ & - & - & - \\
\hline
\end{tabular}




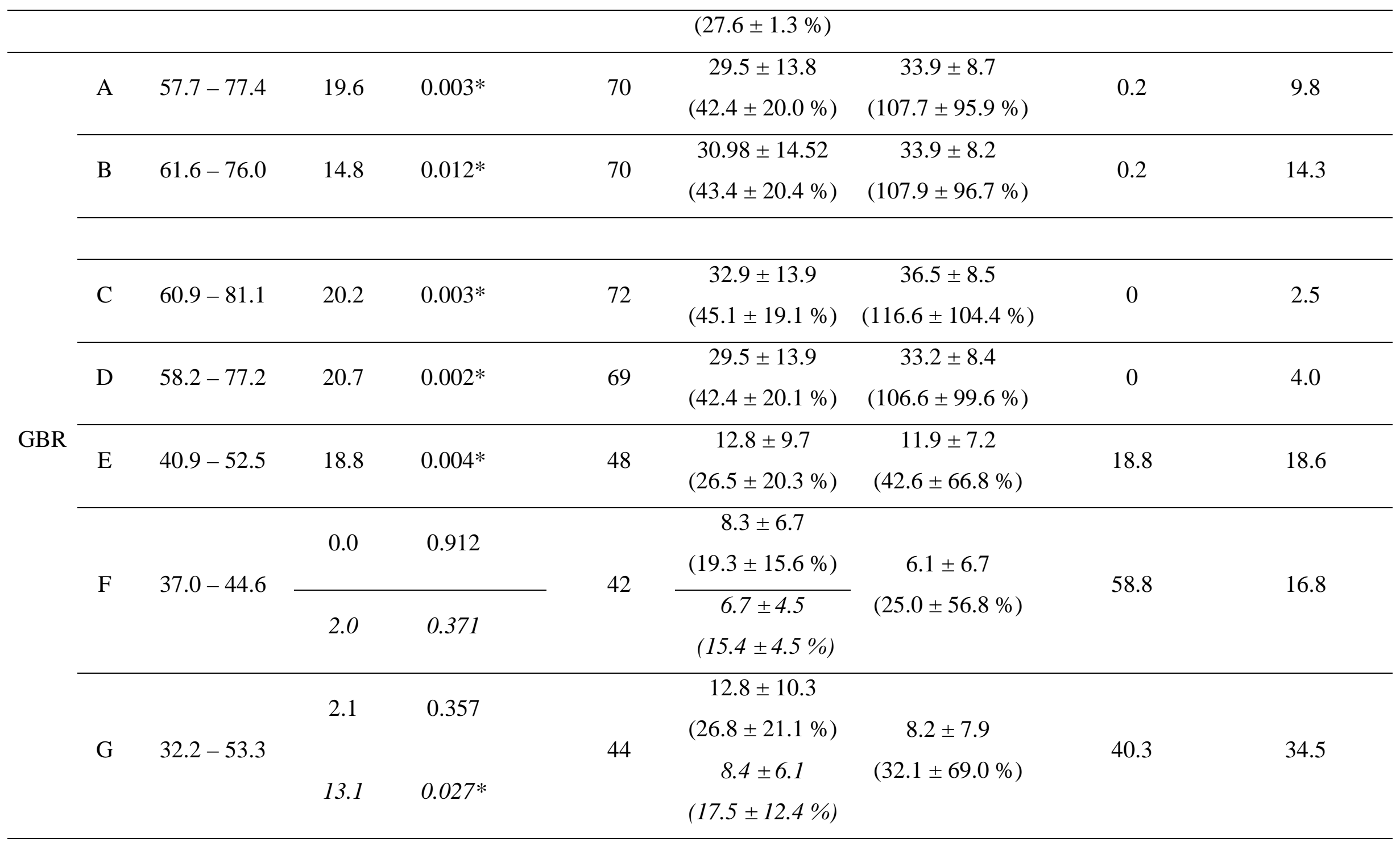




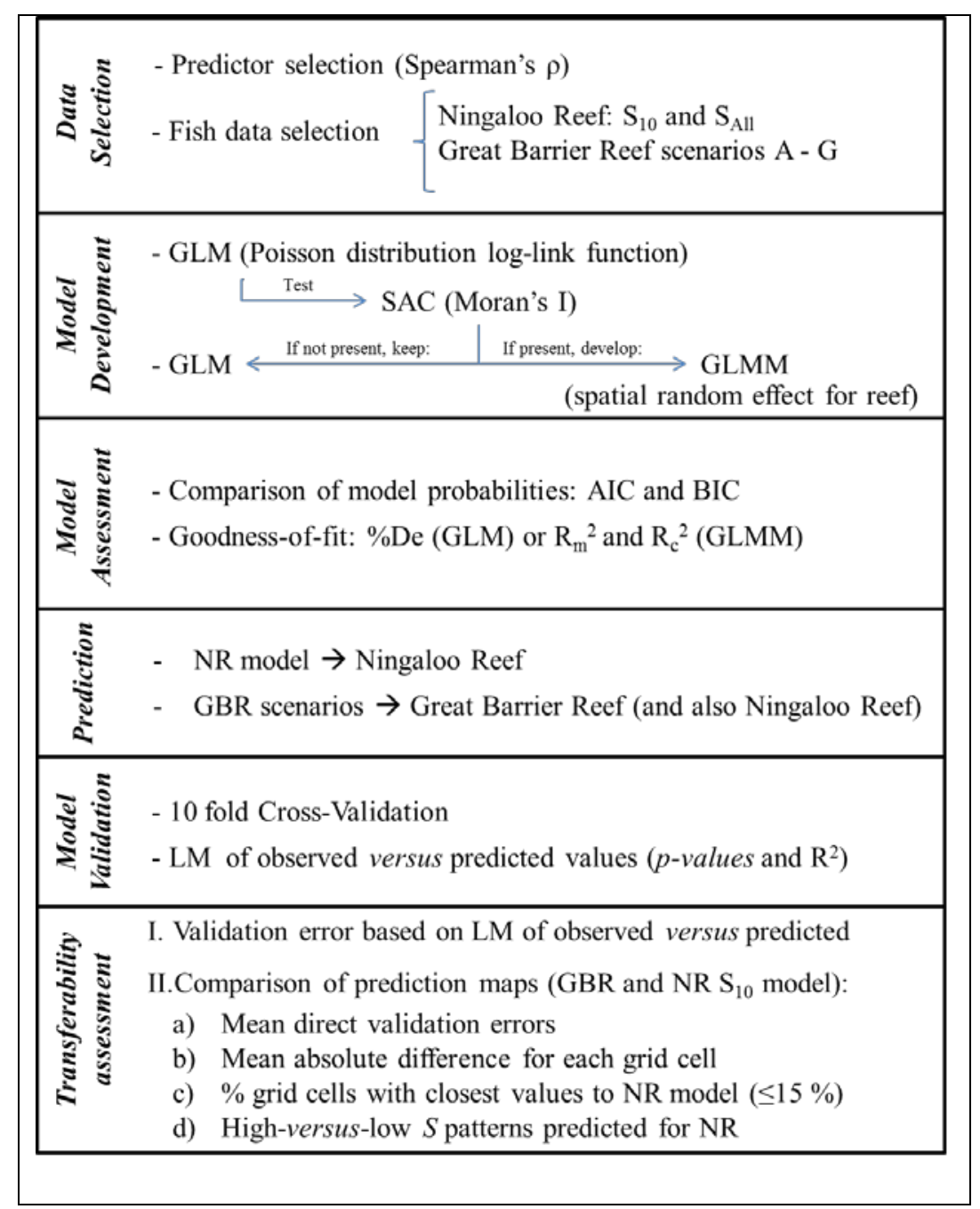

531 Figure 1: The approach used to develop and test transferability of predictive models of fish

532 species richness (S) for the Great Barrier Reef (GBR) to Ningaloo Reef (NR). Two models

533 for NR are included: $S_{10}$ includes the 10 fish families sampled on the GBR and $S_{\text {All }}$ includes

534 all fish families sampled at NR (Appendix 2 in Supplementary Information). We modelled

535 seven GBR scenarios (A to G) each considering a subset of the fish data sampled for the

536 GBR (Table 2). 

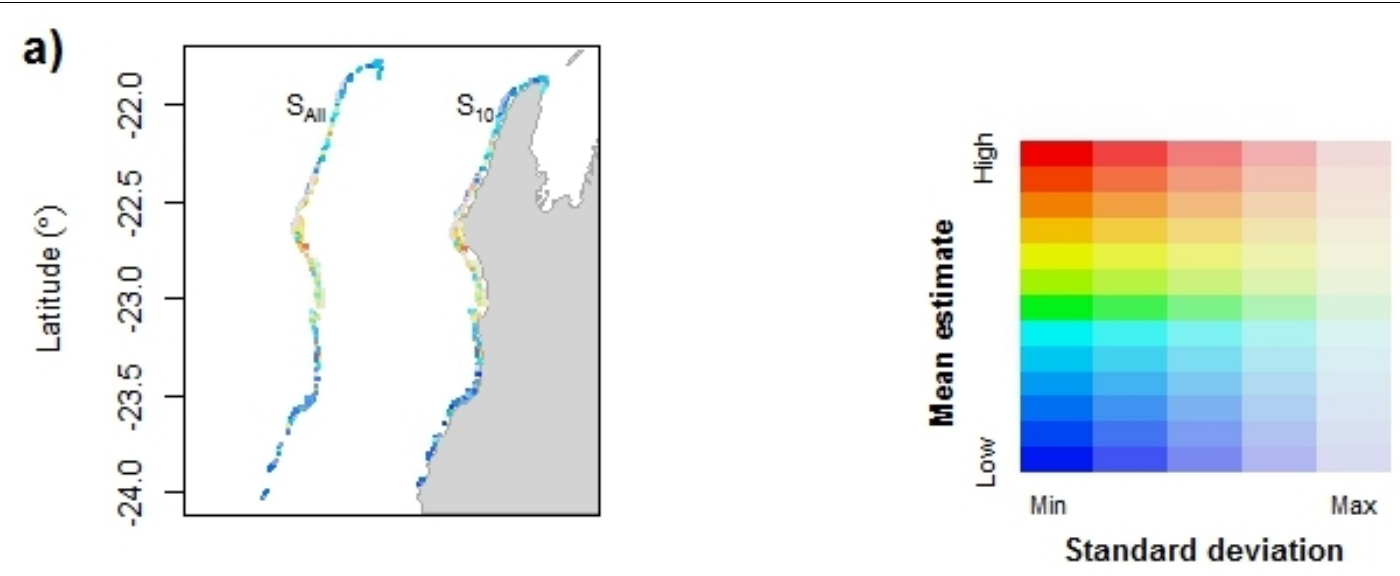

b)

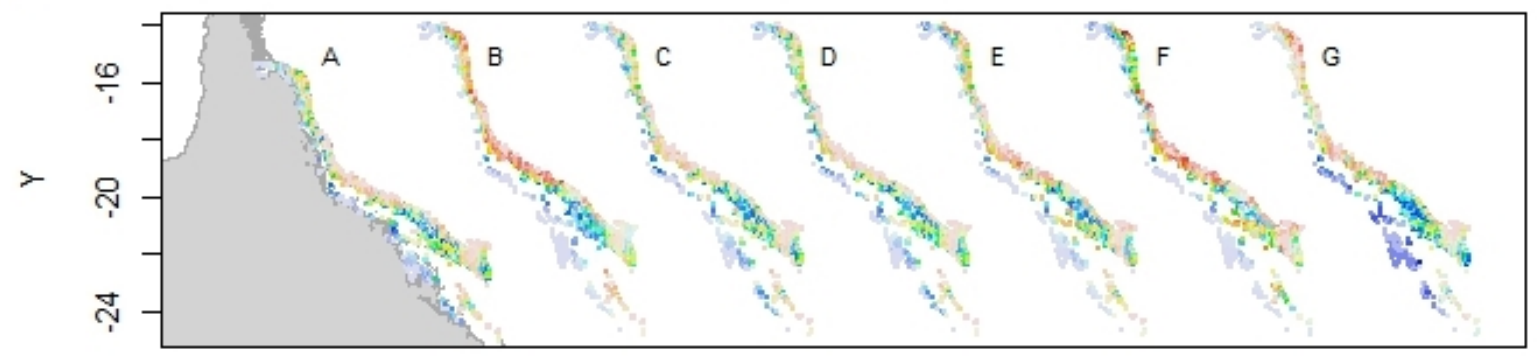

Figure 2: Prediction maps of fish species richness (S) for: a) Ningaloo Reef using all fish data

538 (SAll) and the10 fish families ( $\left.\mathrm{S}_{10}\right)$ sampled on the Great Barrier Reef (GBR); b) the GBR when using different subsets of the fish data sampled in that system (A-G; see Table 2). 


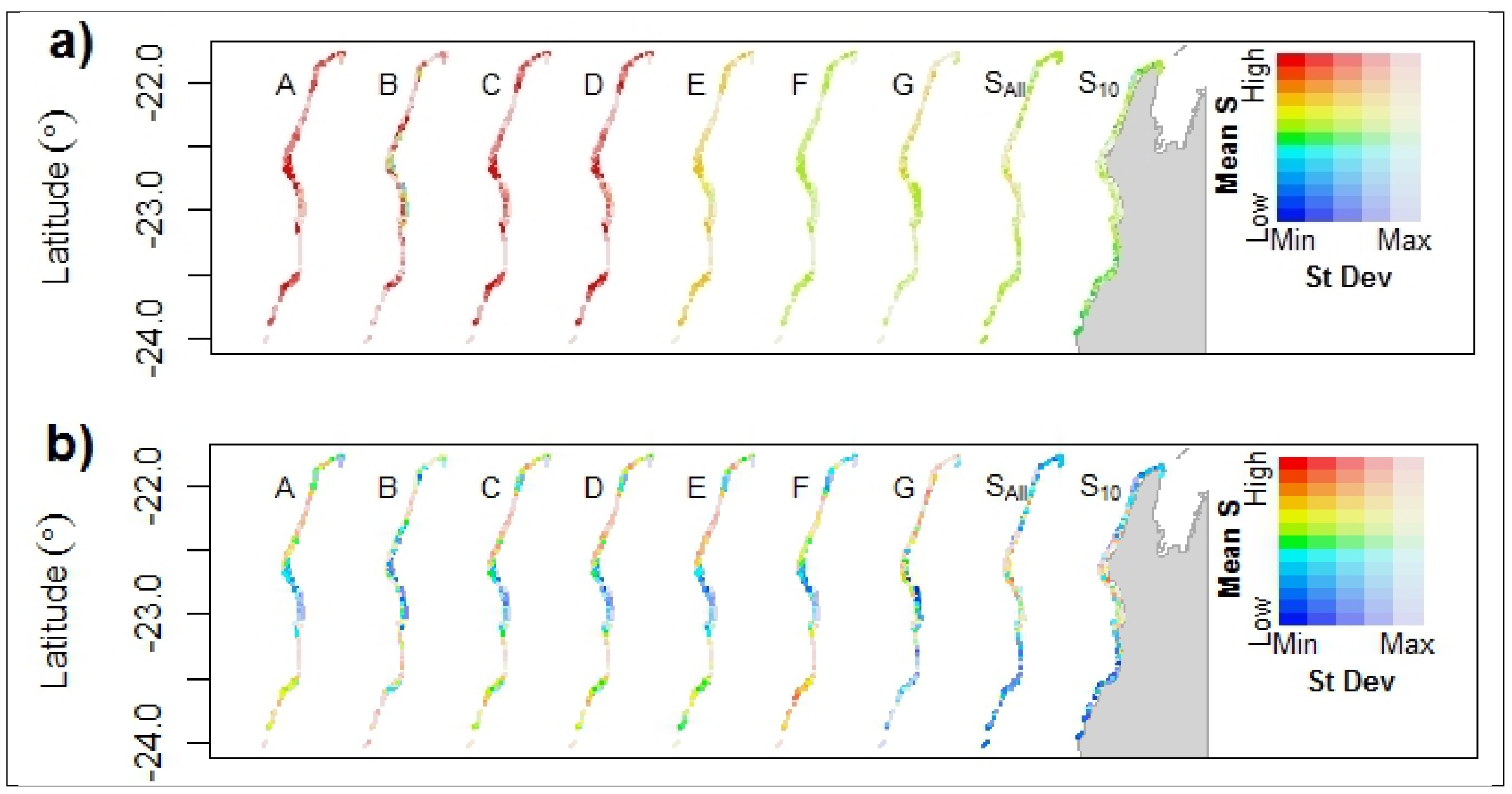




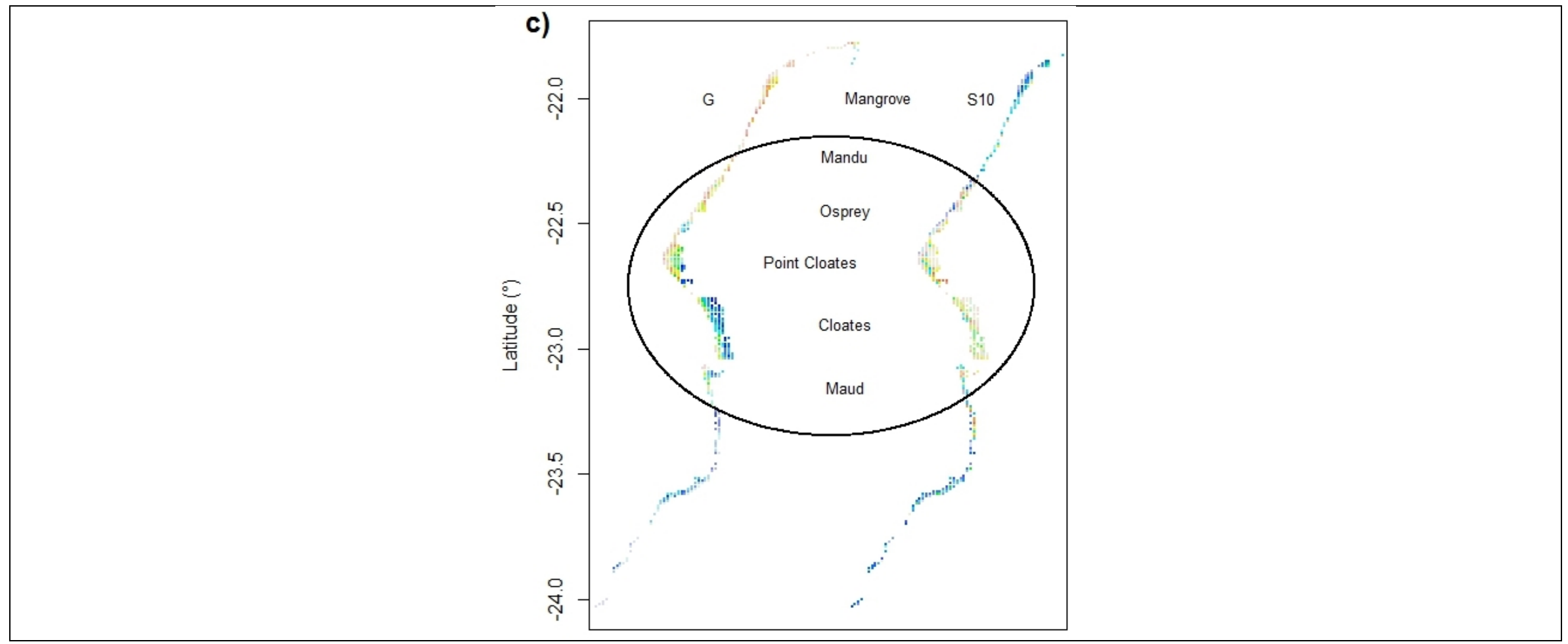

540 Figure 3: Prediction maps of fish species richness (S) at Ningaloo Reef (NR) obtained from GBR scenarios A to G (Table 2) and the NR models

541 (SAll: all species sampled and $\mathrm{S}_{10}$ : species of the 10 families sampled on the GBR). Panel a) highlights differences in prediction ranges from each

542 model. Panel b) allows comparison of areas where greater $S$ was predicted by each model. Panel c) compares prediction results for NR from both

543 the GBR scenario G and the NR model highlighting: (i) the low predictions of $S$ in the southernmost section of NR by both models, (ii) the

544 prediction of higher $S$ in the northernmost section of NR by the GBR scenario G, and (iii) the prediction of greater $S$ in the central (circled) area

545 of NR, with the GBR scenario G predicting higher $S$ towards the reef but not in the lagoon around Cloates. 


\section{Supporting Information}

547 The following additional supporting information may be found in the online version of this 548 article:

549 Appendix S1 Replication of existing GBR models (scenario A) from Mellin et al. (2010)

550 Appendix S2 Supplementary tables

551

552

553

554

555

556

557

558

559

560

561

562

563

564

565

566

567

568

569

Table S1 List of environmental predictors available around Australia with a resolution of 0.01 degrees used in our models and data sources

Table S2 Summary of models predicting fish species richness ( $S$; generalized linear models - GLM and generalized linear mixed-effect models - GLMM) to spatial and environmental properties for the Great Barrier Reef for the period: 2003 to 2007 as per Mellin et al. (2010).

Table S3 Summary of the best performing generalized linear mixed-effect models (GLMMs) for the GBR and model-averaged predictions of reef fish species richness (S) for the Great Barrier Reef (GBR).

\section{Appendix S3: Supplementary figures}

Figure S1 Location of the sampling sites where fish data were collected at Ningaloo Reef and the Great Barrier Reef.

Figure S2 Prediction maps of fish species richness $(S)$ for the Great Barrier Reef and the period 2003 - 2007 obtained using our model replicating Mellin et al. (2010) and reproduced from Mellin et al. (2010)

Figure S3 Model-averaged effect sizes for each predictor included in the generalized linear model (GLM) developed for Ningaloo Reef (NR) and in the generalized linear mixed-effects models (GLMM) developed for each scenario using data collected from the Great Barrier Reef. 
Figure S4 Linear model of predicted fish species richness from the NR models versus observed values for Ningaloo Reef.

572 Appendix S4: References in supplementary material

573 Appendix S5: List of fish species sampled in Ningaloo Reef and the Great Barrier Reef

574 Appendix S6: Zipped folder with R script and data used from Ningaloo Reef

575 


\section{Appendix S1: Replication of existing GBR models}

577 We replicated the models of fish species richness (referred to as "fish species richness in the

578 reference) developed for the GBR by Mellin et al. (2010) using a similar dataset to that used

579 in the original publication: (i) fish data collected on the GBR from 2003 to 2007, and (ii)

580 environmental data extracted from the CERF (Commonwealth of Australia's Environment

581 Research Facility) dataset. However, while Mellin et al. (2010) selected predictors using a

582 multi-step procedure involving both a principal component and a correlation analysis

583 followed by a series of GLM models using, at a time, each predictor and its quadratic term to

584 predict $S$ (Mellin et al. 2010), we simplified the variable selection procedure to be mostly

585 based on non-collinearity of predictors, as described in the main body of the text.

586

Our reproduced GLM models resulted in a similar ranking (Table S2) to that

587 presented in Mellin et al. (2010): the full model got the highest weights for both AICc and

588 BIC, and also explained the greatest deviance ( $60 \%)$. The cross-validation error obtained

589 for this model was $8.6 \pm 1.6$ species. Because we observed strong spatial autocorrelation in

590 the GLM residuals (mostly in the first three lags), we developed GLMM by including a

591 spatial random effect for reef in each model to account for spatial relationships among sites

592 within each reef. No spatial autocorrelation was evident in the GLMM residuals. For these

593 GLMM models comparison with the original publication was not possible as Mellin et al.

594 (2010) used a penalized quasi-likelihood approach (Venables \& Ripley 2002) which does not

595 allow calculation of the likelihood, and therefore no AIC and BIC were computed.

596 We obtained the highest ranks from both information criteria weights (wAICc and

$597 w$ BIC) for the GLMM model including only the coefficient of light attenuation (K490; model

598 11), but these weights were equivalent to those obtained for model 9 (chlorophyll $a$ : Chla)

599 and model 2 (including distances to coast and barrier) (Table S2). The $\mathrm{R}^{2} \mathrm{~m}$ obtained for these

600 three models ranged from 23.1 to 29.9 but the full GLMM model resulted in the highest $\mathrm{R}^{2} \mathrm{~m}$ 
601 (53.1). All $\mathrm{R}^{2}$ c values ranged between 70.9 and 73.7. The predictor with the greatest effect

602 was the linear term for barrier (Fig. S3 - scenario A, as per figure legend), followed by

603 K490, Chla and the percentage of carbonates in the sediment (crbnt). Similar to maps shown

604 in Mellin et al. (2010), the resulting spatial patterns we obtained showed higher $S$ mostly in

605 the northern sections and towards the outer limits of the GBR (Fig. S2). 
607 Table S1: List of environmental predictors available around Australia with a resolution of

6080.01 degrees and used in our models (except predictors highlighted in grey): 1) Australian

609 Bathymetry and Topography Grid Geoscience Australia Record 2005/12 (Webster \&

610 Petkovic, 2005) available at: www.ga.gov.au/products; 2) GEological and Oceanographic

611 Model of Australia’s Continental Shelf (GEOMACS, Hemer, 2006 REF); 3) MARine

612 Sediment Database (MARS; Matthews et al, 2007 REF; Passlow et al, 2005), available at:

613 www.ga.gov.au/oracle/mars; 4) Commonwealth and Scientific Industrial Research

614 Organisation Atlas of Regional Seas (CSIRO - CARS ) (Ridgway et al, 2002; Dunn et al,

615 2002) available at: www.marine.csiro.au; 5) Ocean colour standard monthly data products

616 from the Sea-viewing Wide Field-of-view Sensor (SeaWiFS) and Moderate Resolution

617 Imaging Spectroradiometer satellite (MODIS) from the National Aeronautics and Space

618 Administration (NASA); 6) sourced from the Ocean Productivity Home Page, Oregon State

619 University, U.S. www.science.oregonstate.edu/ocean.productivity; 7) estimated from

620 monthly surface photosynthetic radiation (PAR; SeaWiFs): PAR*exp(K490*depth); 8)

621 NASA standard monthly data products from the Advanced Very High Resolution Radiometer

622 (AVHRR) Pathfinder V5 satellite; 9) calculated using an exponential decay model: flux

623 (depth) $=3.523$ x NPP x depth -0.734 (Biggs et al, 2008; Pace et al, 1987). For more details

624 on the data and links for access refer to Huang et al. (2010) and Pitcher et al. (2012).

\begin{tabular}{llcc}
\hline Variable & \multicolumn{1}{c}{ Description } & Units & Reference \\
\hline Bathy & Depth & $\mathrm{m}$ & 1 \\
Slope & Slope derived from bathymetry & $\circ$ & 1 \\
Aspect & Aspect of slope derived from bathymetry & ${ }^{\circ} \mathrm{T}$ & 1 \\
StressTMN & Trimmed mean of seabed current stress & & 2 \\
StresSIQR & Inter-quartile range of seabed current stress & $\%$ & 2 \\
Crbnt & Percentage of carbonates in sediment & $\%$ & 3 \\
Gravel & Percentage of gravel grainsize fraction in sediment & $\%$ & 3 \\
Sand & Percentage of sand grainsize fraction in sediment & $\%$ & 3 \\
\hline
\end{tabular}




\begin{tabular}{|c|c|c|c|}
\hline Mud & Percentage of mud grainsize fraction in sediment & $\%$ & 3 \\
\hline NO3av & Annual average of nitrate (bottom water) & $\mu \mathrm{M}$ & 4 \\
\hline NO3 sr & Seasonal range of nitrate (bottom water) & & 4 \\
\hline PO4av & Annual average of phosphate (bottom water) & $\mu \mathrm{M}$ & 4 \\
\hline $\mathrm{PO}_{\text {sr }}$ & Seasonal range of phosphate (bottom water) & & 4 \\
\hline $\mathrm{O} 2 \mathrm{av}$ & Annual average of oxygen (bottom water) & $\mathrm{ml} \mathrm{L}^{-1}$ & 4 \\
\hline $\mathrm{O} 2_{\mathrm{sr}}$ & Seasonal range of oxygen (bottom water) & & 4 \\
\hline $\mathrm{S}_{\mathrm{av}}$ & Annual average of salinity (bottom water) & $\%$ (ppt) & 4 \\
\hline $\mathrm{S}_{\mathrm{sr}}$ & Seasonal range of salinity (bottom water) & & 4 \\
\hline $\mathrm{T}_{\mathrm{av}}$ & Annual average of temperature (bottom water) & ${ }^{\circ} \mathrm{C}$ & 4 \\
\hline $\mathrm{T}_{\mathrm{sr}}$ & Seasonal range of temperature (bottom water) & & 4 \\
\hline SIav & Annual average of silicate (bottom water) & $\mu \mathrm{M}$ & 4 \\
\hline $\mathrm{SI}_{\mathrm{sr}}$ & Seasonal range of silicates (bottom water) & & 4 \\
\hline Chla $_{a v}$ & Mean sea surface chlorophyll $a$ concentration & $\mathrm{mg} \cdot \mathrm{m}^{3}$ & 5 \\
\hline Chla $_{\text {sr }}$ & Seasonal range of sea surface chlorophyll $a$ concentration & & 5 \\
\hline K490av & Mean diffuse attenuation coefficient at wavelength 490nm & $\mathrm{m}^{-1}$ & 5 \\
\hline $\mathrm{K} 490_{\text {sr }}$ & Seasonal range of mean diffuse attenuation coefficient & & 5 \\
\hline $\mathrm{PAR}_{\mathrm{av}}$ & Available surface of photosynthetic radiation & Einstein $\mathrm{m}^{-2}$ day $^{-1}$ & 5 \\
\hline $\mathrm{PAR}_{\mathrm{sr}}$ & Seasonal range of available surface photosynthetic radiation & & 5 \\
\hline $\mathrm{VGPM}_{\mathrm{av}}$ & Annual average of net primary production & $\mathrm{mg} \mathrm{C} \mathrm{m} \mathrm{m}^{-2} \mathrm{~d}^{-1}$ & 6 \\
\hline $\mathrm{VGPM}_{\mathrm{sr}}$ & Seasonal range of net primary production & & 6 \\
\hline $\mathrm{BIR}$ av & Annual average of benthic irradiance & & 7 \\
\hline $\mathrm{BIR}_{\mathrm{sr}}$ & Seasonal range of benthic irradiance & & 7 \\
\hline $\mathrm{SST}_{\mathrm{av}}$ & Annual average of sea surface temperature & ${ }^{\circ} \mathrm{C}$ & 8 \\
\hline $\mathrm{SST}_{\mathrm{sr}}$ & Seasonal range of sea surface temperature & & 8 \\
\hline $\mathrm{EPOC}_{\text {av }}$ & Annual average of exported particulate organic carbon flux & $\mathrm{mg} \mathrm{C} \mathrm{m} \mathrm{m}^{-2} \mathrm{~d}^{-1}$ & 9 \\
\hline $\mathrm{EPOC}_{\mathrm{sr}}$ & Seasonal range of exported particulate organic carbon flux & & 9 \\
\hline
\end{tabular}


Table S2: Summary of models predicting fish species richness (S; generalized linear models - GLM and generalized linear mixed-effect models

- GLMM) to spatial and environmental properties for the Great Barrier Reef for the period: 2003 to 2007 as per Mellin et al. (2010). Note that in

627 Mellin et al. (2010), S is referred to as "fish species richness". Shown for each model are the biased-corrected model probabilities based on

629 ( $w$ BIC, only $>0.001$ shown), the percentage of deviance explained (\%De for GLM), the cross-validation error (CV error), and both the marginal

630 and conditional $\mathrm{R}^{2}$ for GLMM $\left(R^{2}{ }_{m}\right.$ and $R^{2}$ ) (Nakagawa \& Schielzeth 2013). GLMM include reef as a random effect. Bold case indicates highest

631 rankings from $w \mathrm{AIC}_{c}$ for each model set.

\begin{tabular}{|c|c|c|c|c|c|c|c|c|c|}
\hline \multirow{2}{*}{ Model } & \multicolumn{4}{|c|}{ GLM } & \multicolumn{5}{|c|}{ GLMM } \\
\hline & $\mathrm{wAIC}_{c}$ & $w B I C$ & $\% \mathrm{De} / \mathrm{R}^{2}$ & $\mathbf{C V}_{\text {error }}$ & $w \mathrm{AIC}_{c}$ & $w B I C$ & $\mathrm{CV}_{\text {error }}$ & $R_{m}^{2}$ & $R^{2}{ }_{c}$ \\
\hline 1 & 1.000 & 1.000 & 58.1 & $8.6 \pm 1.6$ & 0.085 & $<0.001$ & $15.5 \pm 3.9$ & 53.1 & 70.9 \\
\hline 2 & $<0.001$ & - & - & - & 0.170 & 0.005 & $18.0 \pm 4.1$ & 29.9 & 72.3 \\
\hline 4 & $<0.001$ & - & - & - & 0.027 & 0.010 & $11.3 \pm 2.1$ & 19.6 & 73.2 \\
\hline 9 & $<0.001$ & - & - & - & 0.214 & 0.299 & $10.0 \pm 2.0$ & 23.1 & 73.3 \\
\hline 10 & $<0.001$ & - & - & - & 0.021 & 0.008 & $16.8 \pm 2.9$ & 19.1 & 72.6 \\
\hline 11 & $<0.001$ & - & - & - & 0.479 & 0.671 & $10.0 \pm 2.1$ & 25.0 & 73.6 \\
\hline
\end{tabular}



reef fish species richness $(S)$ for the Great Barrier Reef (GBR). For each scenario (refer to Table 2 for details on each scenario), the biased-

634 corrected model probabilities based on weights of Akaike’s information criterion corrected for small sample sizes (wAICc), Bayesian

635 information criteria ( $w$ BIC, only $>0.001$ shown), marginal $\left(R^{2} \mathrm{~m}\right)$ and conditional $\mathrm{R}^{2}\left(R^{2} c\right)$ (Nakagawa, 2013), and the cross-validation error

636 ( $C V_{\text {error }}$ ) are reported. Model-averaged predictions obtained for each scenario when predicting to the GBR show the predicted range (Range) and 637 the model-averaged cross-validation error ( $\mathrm{CV}$ error_av).

\begin{tabular}{|c|c|c|c|c|c|c|c|c|}
\hline \multirow[b]{2}{*}{ Scenario } & \multicolumn{6}{|c|}{ Best model performance } & \multicolumn{2}{|c|}{ Model-averaged predictions } \\
\hline & Model & wAIC $_{c}$ & $w \mathrm{BIC}$ & $\mathbf{R}^{2} \mathbf{m}$ & $\mathbf{R}^{2}{ }_{\mathbf{c}}$ & $\mathbf{C V}_{\text {error }}$ & $\begin{array}{l}\text { Range } \\
\text { (St Dev) }\end{array}$ & CV $V_{\text {error_av }}$ \\
\hline A & 11 & 0.479 & 0.671 & 25.0 & 73.6 & $10.0 \pm 2.1$ & $\begin{array}{c}31.3-84.0 \\
(0.98-6.16)\end{array}$ & $12.4 \pm 2.6$ \\
\hline B & 2 & 0.636 & 0.049 & 32.7 & 72.4 & $18.4 \pm 3.7$ & $\begin{array}{c}59.4-74.4 \\
(1.49-3.37)\end{array}$ & $12.2 \pm 2.4$ \\
\hline $\mathbf{C}$ & 11 & 0.654 & 0.871 & 27.4 & 77.1 & $11.6 \pm 1.9$ & $\begin{array}{c}30.8-92.0 \\
(0.71-2.00)\end{array}$ & $14.3 \pm 2.6$ \\
\hline $\mathbf{D}$ & 11 & 0.615 & 0.858 & 26.6 & 76.4 & $11.3 \pm 2.5$ & $\begin{array}{c}31.3-86.7 \\
(0.75-1.84)\end{array}$ & $13.6 \pm 2.5$ \\
\hline
\end{tabular}




\begin{tabular}{|c|c|c|c|c|c|c|c|c|}
\hline $\mathbf{E}$ & 11 & 0.681 & 0.841 & 23.1 & 71.0 & $8.5 \pm 1.7$ & $\begin{array}{c}19.9-61.0 \\
(0.50-1.29)\end{array}$ & $10.1 \pm 2.1$ \\
\hline \multirow[b]{2}{*}{$\mathbf{F}$} & 11 & 0.483 & 0.691 & 18.1 & 67.6 & $7.8 \pm 1.5$ & \multirow[b]{2}{*}{$\begin{array}{c}21.2-50.5 \\
(0.70-2.34)\end{array}$} & \multirow[b]{2}{*}{$8.9 \pm 1.8$} \\
\hline & 4 & 0.259 & 0.094 & 19.2 & 68.1 & $7.9 \pm 1.5$ & & \\
\hline \multirow{2}{*}{ G } & 10 & 0.398 & 0.510 & 31.6 & 83.0 & $10.1 \pm 2.5$ & \multirow{2}{*}{$\begin{array}{c}20.2-65.7 \\
(1.76-17.9)\end{array}$} & \multirow{2}{*}{$12.7 \pm 2.6$} \\
\hline & 1 & 0.366 & $<0.001$ & 57.5 & 83.8 & $20.9 \pm 5.0$ & & \\
\hline
\end{tabular}


640 Figure S1: Location of the sampling sites where fish data were collected at a) Ningaloo Reef

641 (spanning $\sim 2^{\circ}$ latitude) and b) the Great Barrier Reef (spanning 15 ${ }^{\circ}$ latitude) (from Mellin

642 et al., 2010). Numbers indicate locations for each latitudinal region; as per Mellin et al.,

643 2010).

a)

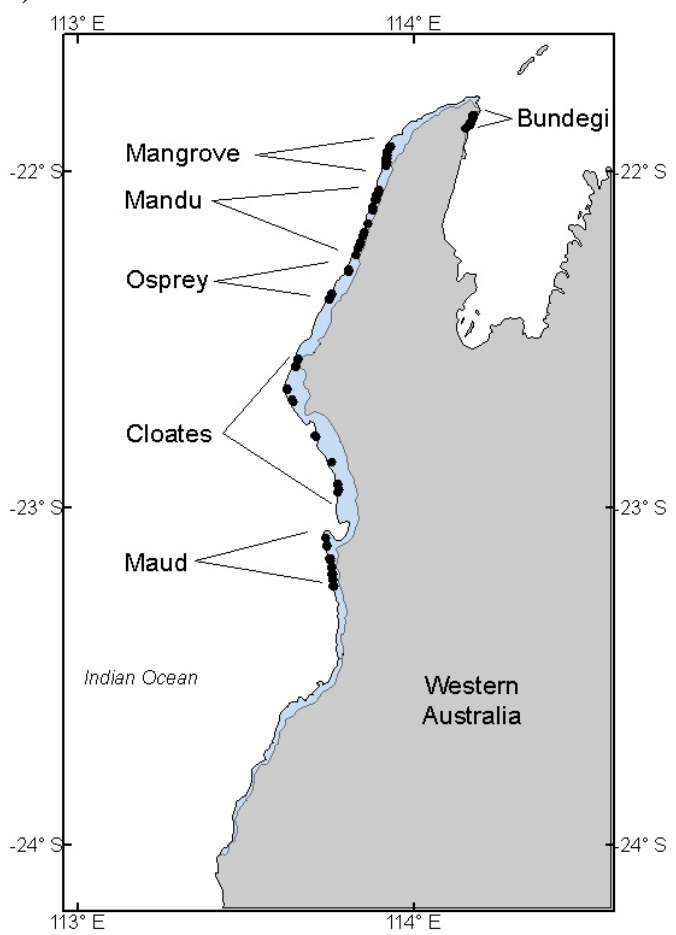

b)

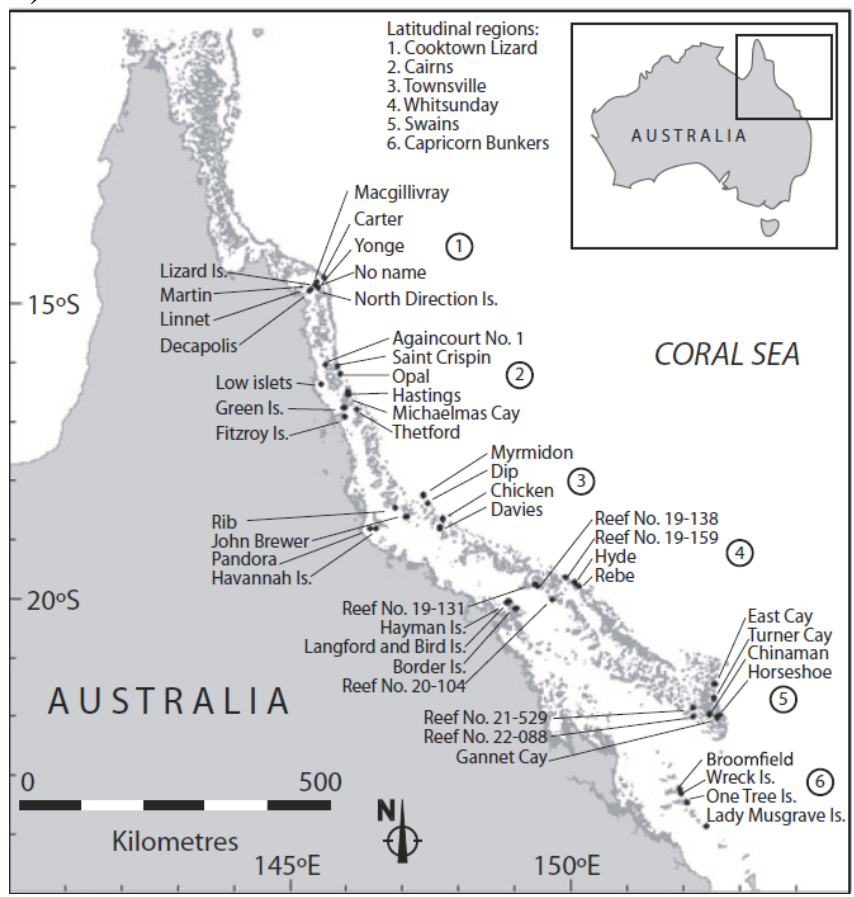

644 
645 Figure S2: Prediction maps of fish species richness (S) for the Great Barrier Reef and the period 2003 - 2007 obtained using our model

646 replicating Mellin et al. (2010) (i.e., scenario A) (left) and reproduced from Mellin et al. (2010) (right).
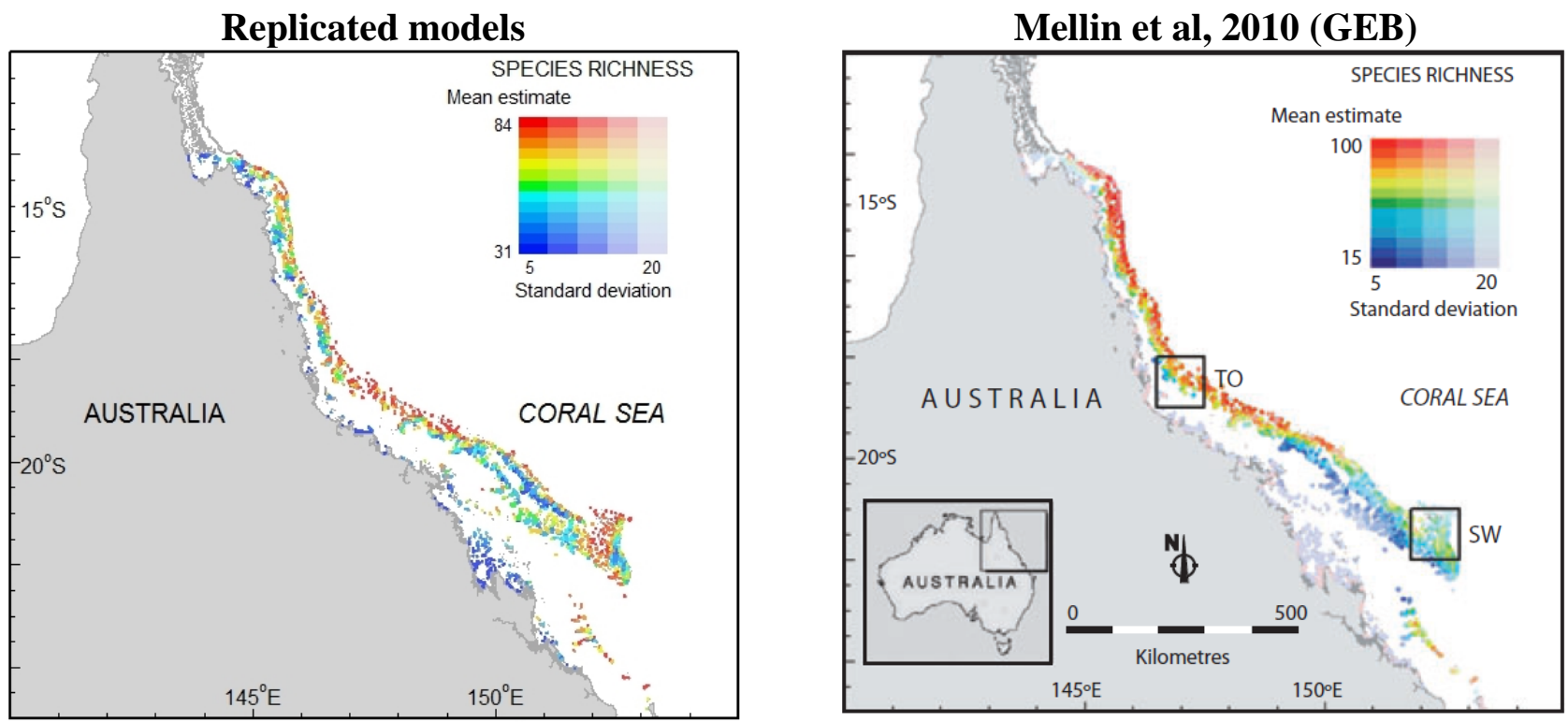
647 Figure S3: Model-averaged effect sizes for each predictor included in the generalized linear

648 model (GLM) developed for Ningaloo Reef (NR) and in the generalized linear mixed-effects

649 models (GLMM) developed for each scenario using data collected from the Great Barrier

650 Reef. For details on predictors and scenarios (A to G) refer to Table 1 and Table 2,

651 respectively.

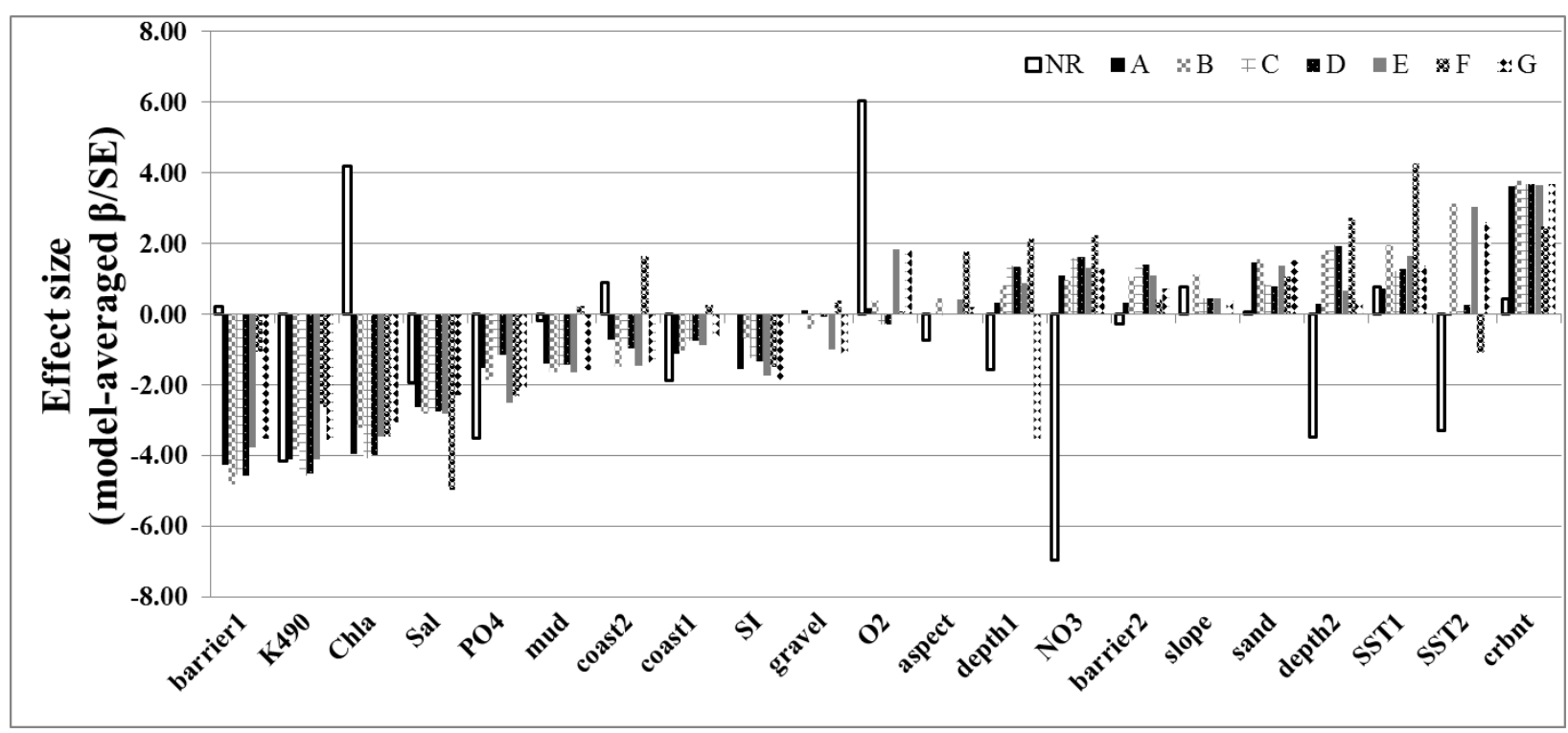

652 
653 Figure S4: Linear model of predicted fish species richness from the NR models versus

654 observed values for Ningaloo Reef. Left: NR model using all species data sampled ( $\left.S_{\text {All }}\right)$ :

$655 \mathrm{R}^{2}=0.396$ and $p$-value $<0.001$; Right: NR model using only species from the same 10

656 families sampled in the Great Barrier Reef $\left(S_{10}\right): \mathrm{R}^{2}=0.437$ and $p$-value $<0.001$.
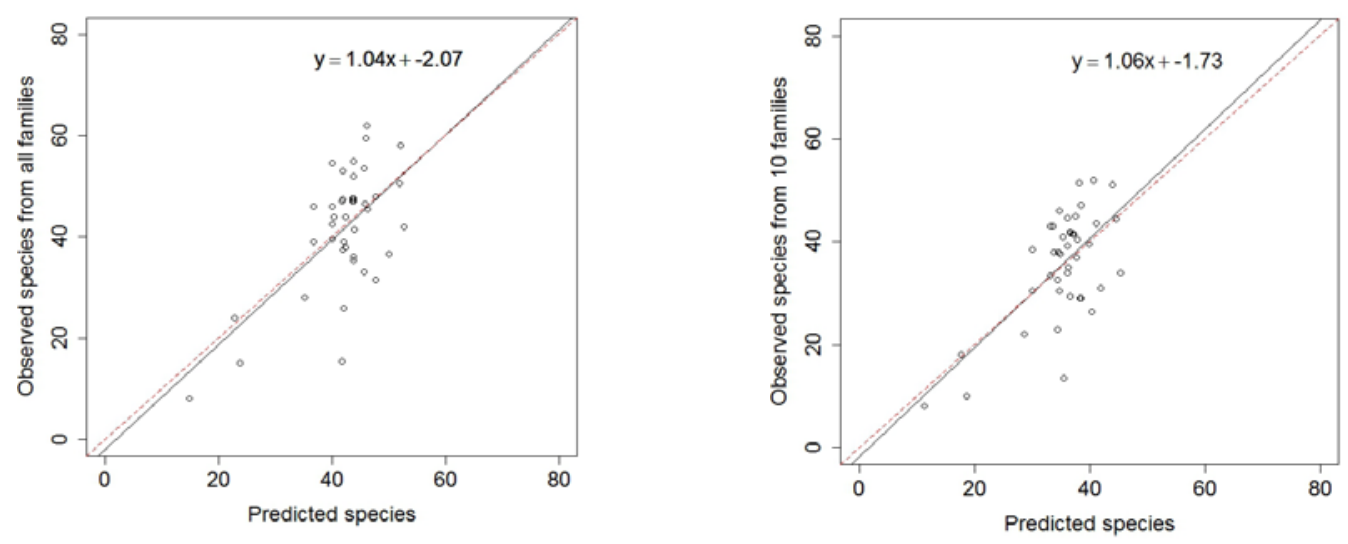

657 
659 Biggs, D.C., Hu, C. \& Müller-Karger, F.E. (2008) Remotely sensed sea-surface chlorophyll and POC flux at Deep Gulf of Mexico Benthos sampling stations. Deep Sea Research

661 Part II: Topical Studies in Oceanography, 55, 2555-2562

662 Pace, M.L., Knauer, G.A., Karl, D.M. \& Martin, J.H. (1987) Primary production, new production and vertical flux in the eastern Pacific Ocean. Nature, 325, 803-804

Dunn J.R. \& Ridgway, K.R. (2002) Mapping ocean properties in regions of complex topography. Deep Sea Research I: Oceanographic Research, 49, 591-604

Huang, Z., Brooke, B., Whitta, N., Potter, A., Fuller, M., Dunn, J. \& Pitcher, R. (2010) Australian Marine Physical Environmental Data - Descriptions and Metadata. Record 2010/32, pp. 141. Geoscience Australia

Pace, M.L., Knauer, G.A., Karl, D.M. \& Martin, J.H. (1987) Primary production, new production and vertical flux in the eastern Pacific Ocean. Nature, 325, 803-804.

Passlow, V., Rogis, J., Hancock, A., Hemer, M., Glenn, K. \& Habib, A. (2005) National marine sediments database and seafloor characteristics project, final report. Geoscience Australia, Record 2005/08

Pitcher, C.R., Lawton, P., Ellis, N., Smith, S.J., Incze, L.S., Wei, C.-L., Greenlaw, M.E., Wolff, N.H., Sameoto, J.A. \& Snelgrove, P.V.R. (2012) Exploring the role of environmental variables in shaping patterns of seabed biodiversity composition in regional-scale ecosystems. Journal of Applied Ecology, 49, 670-679. least squares - Application to the waters around Australia, Journal of Atmospheric and Ocean Technology, 19, 1357-1375. 
681 Webster, M.A. \& Petkovic, P. (2005) Australian Bathymetry and Topography Grid, June 682 2005. Geoscience Australia Record 2005/12.

683 http://www.ga.gov.au/meta/ANZCW0703008022.html

684 
685 Appendix S5: List of fish species sampled on the Great Barrier Reef (GBR) and

686 Ningaloo Reef (NR). In the GBR only the following ten fish families were sampled:

687 Acanthuridae, Chaetodontidae, Labridae, Lethrinidae, Lutjanidae, Pomacentridae,

688 Scaridae, Serranidae, Siganidae, and Zanclidae. All rows including other families only

689 sampled in Ningaloo Reef are shown in grey.

Family

Acanthuridae
Apogonidae

Aulostomidae

Balistidae

Belonidae

Blenniidae
Species

Acanthurus albipectoralis

Acanthurus auranticavus

Acanthurus bariene

Acanthurus blochii

Acanthurus dussumieri

Acanthurus grammoptilus

Acanthurus lineatus

Acanthurus maculiceps

Acanthurus mata

Acanthurus nigricans

Acanthurus nigricauda

Acanthurus nigrofuscus

Acanthurus olivaceus

Acanthurus pyroferus

Acanthurus thompsoni

Acanthurus triostegus

Acanthurus xanthopterus

Ctenochaetus striatus

Naso annulatus

Naso fageni

Naso lituratus

Naso tuberosus

Naso unicornis

Paracanthurus hepatus

Zebrasoma scopas

Zebrasoma veliferum

Apogon taeniophorus

Aulostomus chinensis

Pseudobalistes fuscus

Rhinecanthus aculeatus

Rhinecanthus rectangulus

Sufflamen chrysopterum

cf Platybelone argalus

Tylosurus crocodiles

Aspidontus taeniatus

\section{GBR NR}

$\checkmark$

$\sqrt{ }$

$\sqrt{ }$

$\checkmark$

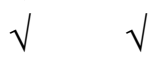

$\sqrt{ }$

$\sqrt{ }$

$\checkmark$

$\sqrt{ } \quad \sqrt{ }$

$\sqrt{ }$ V

$\sqrt{ }$

$\sqrt{ } \quad \sqrt{ }$

$\sqrt{ }$

$\sqrt{ }$

$\sqrt{ } \quad \sqrt{ }$

$\checkmark$

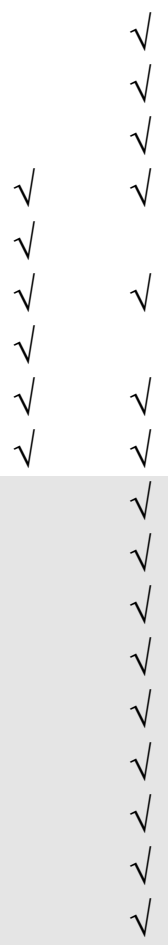




\begin{tabular}{|c|c|c|c|}
\hline \multirow{5}{*}{ Carangidae } & \multicolumn{2}{|l|}{ Meiacanthus grammistes } & $\sqrt{ }$ \\
\hline & \multicolumn{2}{|l|}{ Carangoides ferdau } & $\sqrt{ }$ \\
\hline & \multicolumn{2}{|l|}{ Carangoides fulvoguttatus } & $\sqrt{ }$ \\
\hline & \multicolumn{2}{|l|}{ Caranx ignobilis } & $\sqrt{ }$ \\
\hline & \multicolumn{2}{|l|}{ Gnathanodon speciosus } & $\sqrt{ }$ \\
\hline Carcharhinidae & \multicolumn{2}{|l|}{ Carcharhinus amblyrhynchos } & $\sqrt{ }$ \\
\hline & \multicolumn{2}{|l|}{ Carcharhinus melanopterus } & $\sqrt{ }$ \\
\hline & \multicolumn{2}{|l|}{ Triaenodon obesus } & $\sqrt{ }$ \\
\hline \multirow[t]{37}{*}{ Chaetodontidae } & \multicolumn{2}{|l|}{ Chaetodon adiergastos } & $\sqrt{ }$ \\
\hline & \multicolumn{2}{|l|}{ Chaetodon andamanensis } & $\sqrt{ }$ \\
\hline & \multicolumn{2}{|l|}{ Chaetodon assarius } & $\sqrt{ }$ \\
\hline & Chaetodon aureofasciatus & $\sqrt{ }$ & $\sqrt{ }$ \\
\hline & Chaetodon auriga & $\sqrt{ }$ & $\sqrt{ }$ \\
\hline & Chaetodon baronessa & $\sqrt{ }$ & $\sqrt{ }$ \\
\hline & Chaetodon bennetti & $\sqrt{ }$ & \\
\hline & Chaetodon citrinellus & $\sqrt{ }$ & $\sqrt{ }$ \\
\hline & Chaetodon ephippium & $\sqrt{ }$ & $\sqrt{ }$ \\
\hline & Chaetodon flavirostris & $\sqrt{ }$ & \\
\hline & Chaetodon interruptus & & $\sqrt{ }$ \\
\hline & Chaetodon kleinii & $\sqrt{ }$ & $\sqrt{ }$ \\
\hline & Chaetodon lineolatus & $\sqrt{ }$ & $\sqrt{ }$ \\
\hline & Chaetodon lunula & $\sqrt{ }$ & $\sqrt{ }$ \\
\hline & Chaetodon melannotus & $\sqrt{ }$ & $\sqrt{ }$ \\
\hline & Chaetodon mertensii & $\sqrt{ }$ & \\
\hline & Chaetodon meyeri & $\sqrt{ }$ & \\
\hline & Chaetodon ornatissimus & $\sqrt{ }$ & $\sqrt{ }$ \\
\hline & Chaetodon oxycephalus & $\sqrt{ }$ & \\
\hline & Chaetodon pelewensis & $\sqrt{ }$ & $\sqrt{ }$ \\
\hline & Chaetodon plebeius & $\sqrt{ }$ & $\sqrt{ }$ \\
\hline & Chaetodon punctatofasciatus & $\sqrt{ }$ & $\sqrt{ }$ \\
\hline & Chaetodon rafflesia & $\sqrt{ }$ & \\
\hline & Chaetodon rainfordi & $\sqrt{ }$ & \\
\hline & Chaetodon reticulates & $\sqrt{ }$ & \\
\hline & Chaetodon speculum & $\sqrt{ }$ & $\sqrt{ }$ \\
\hline & Chaetodon trifascialis & $\sqrt{ }$ & $\sqrt{ }$ \\
\hline & Chaetodon trifasciatus & $\sqrt{ }$ & $\sqrt{ }$ \\
\hline & Chaetodon ulietensis & $\sqrt{ }$ & $\sqrt{ }$ \\
\hline & Chaetodon unimaculatus & $\sqrt{ }$ & $\sqrt{ }$ \\
\hline & Chaetodon vagabundus & $\sqrt{ }$ & $\sqrt{ }$ \\
\hline & Chelmon marginalis & & $\sqrt{ }$ \\
\hline & Chelmon rostratus & $\sqrt{ }$ & \\
\hline & Forcipiger flavissimus & $\sqrt{ }$ & \\
\hline & Forcipiger longirostris & $\sqrt{ }$ & \\
\hline & Hemitaurichthys polylepis & $\sqrt{ }$ & \\
\hline & Heniochus acuminatus & & $\sqrt{ }$ \\
\hline
\end{tabular}




\begin{tabular}{|c|c|c|c|}
\hline Chanidae & Chanos chanos & & $\sqrt{ }$ \\
\hline Cirrhitidae & Cirrhitidae spp & & $\sqrt{ }$ \\
\hline Dasyatidae & Taeniura lymma & & $\sqrt{ }$ \\
\hline Diodontidae & Diodon hystrix & & $\sqrt{ }$ \\
\hline Echeneidae & Remora spp & & $\sqrt{ }$ \\
\hline Ephippidae & Platax teira & & $\sqrt{ }$ \\
\hline Fistulariidae & Fistularia commersonnii & & $\sqrt{ }$ \\
\hline & Fistularia petimba & & $\sqrt{ }$ \\
\hline \multirow{3}{*}{$\begin{array}{c}\text { Ginglymostomatidae } \\
\text { Gobiidae }\end{array}$} & Nebrius ferrugineus & & $\sqrt{ }$ \\
\hline & Amblygobius phalaena & & $\sqrt{ }$ \\
\hline & Valenciennea longipinnis & & $\sqrt{ }$ \\
\hline \multirow[t]{4}{*}{ Haemulidae } & Diagramma pictum & & $\sqrt{ }$ \\
\hline & Plectorhinchus chaetodonoides & & $\sqrt{ }$ \\
\hline & Plectorhinchus flavomaculatus & & $\sqrt{ }$ \\
\hline & Plectorhinchus multivittatus & & $\sqrt{ }$ \\
\hline \multirow{6}{*}{$\begin{array}{c}\text { Hemiramphidae } \\
\text { Hemiscylliidae } \\
\text { Kyphosidae }\end{array}$} & Hyporhamphus dussumieri & & $\sqrt{ }$ \\
\hline & Hemiscyllium ocellatum & & $\sqrt{ }$ \\
\hline & Kyphosus bigibbus & & $\sqrt{ }$ \\
\hline & Kyphosus cornelii & & $\sqrt{ }$ \\
\hline & Kyphosus sydneyanus & & $\sqrt{ }$ \\
\hline & Kyphosus vaigiensis & & $\sqrt{ }$ \\
\hline \multirow[t]{24}{*}{ Labridae } & Anampses caeruleopunctatus & & $\sqrt{ }$ \\
\hline & Anampses geographicus & & $\sqrt{ }$ \\
\hline & Anampses lennardi & & 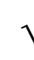 \\
\hline & Anampses meleagrides & & 1 \\
\hline & Bodianus bilineatus & & 1 \\
\hline & Bodianus bilunulatus & & 1 \\
\hline & Cheilinus chlorourus & & \\
\hline & Cheilinus fasciatus & $\sqrt{ }$ & \\
\hline & Cheilinus trilobatus & & \\
\hline & Cheilinus undulatus & $\sqrt{ }$ & \\
\hline & Cheilio inermis & & \\
\hline & Choerodon cauteroma & & \\
\hline & Choerodon cyanodus & & \\
\hline & Choerodon fasciatus & $\sqrt{ }$ & \\
\hline & Choerodon monostigma & & \\
\hline & Choerodon rubescens & & 1 \\
\hline & Choerodon schoenleinii & & 1 \\
\hline & Coris aygula & & \\
\hline & Coris caudimacula & & \\
\hline & Coris dorsomacula & & \\
\hline & Coris gaimard & $\sqrt{ }$ & \\
\hline & Diproctacanthus xanthurus & & \\
\hline & Epibulus insidiator & $\sqrt{ }$ & \\
\hline & Gomphosus varius & $\sqrt{ }$ & \\
\hline
\end{tabular}


Halichoeres biocellatus

Halichoeres hortulanus

Halichoeres lamarii

Halichoeres marginatus

Halichoeres nebulosus

Halichoeres richmondi

Halichoeres trimaculatus

Hemigymnus fasciatus

Hemigymnus melapterus

Hologymnosus annulatus

Labrichthys unilineatus

Labroides dimidiatus

Novaculichthys taeniourus

Stethojulis bandanensis

Thalassoma hardwicke

Thalassoma lunare

Thalassoma lutescens

Psammoperca waigiensis

Lethrinidae

Lethrinus atkinsoni

Lethrinus erythracanthus

Lethrinus harak

Lethrinus laticaudis

Lethrinus lentjan

Lethrinus miniatus

Lethrinus nebulosus

Lethrinus obsoletus

Lethrinus olivaceus

Lethrinus ornatus

Lethrinus rubrioperculatus

Lethrinus semicinctus

Lethrinus xanthochilus

Monotaxis grandoculis

Lutjanidae Lutjanus adetii

Lutjanus argentimaculatus

Lutjanus biguttatus

Lutjanus bohar

Lutjanus boutton

Lutjanus carponotatus

Lutjanus decussatus

Lutjanus fulviflammus

Lutjanus fulvus

Lutjanus gibbus

Lutjanus kasmira

Lutjanus lemniscatus

Lutjanus lutjanus 


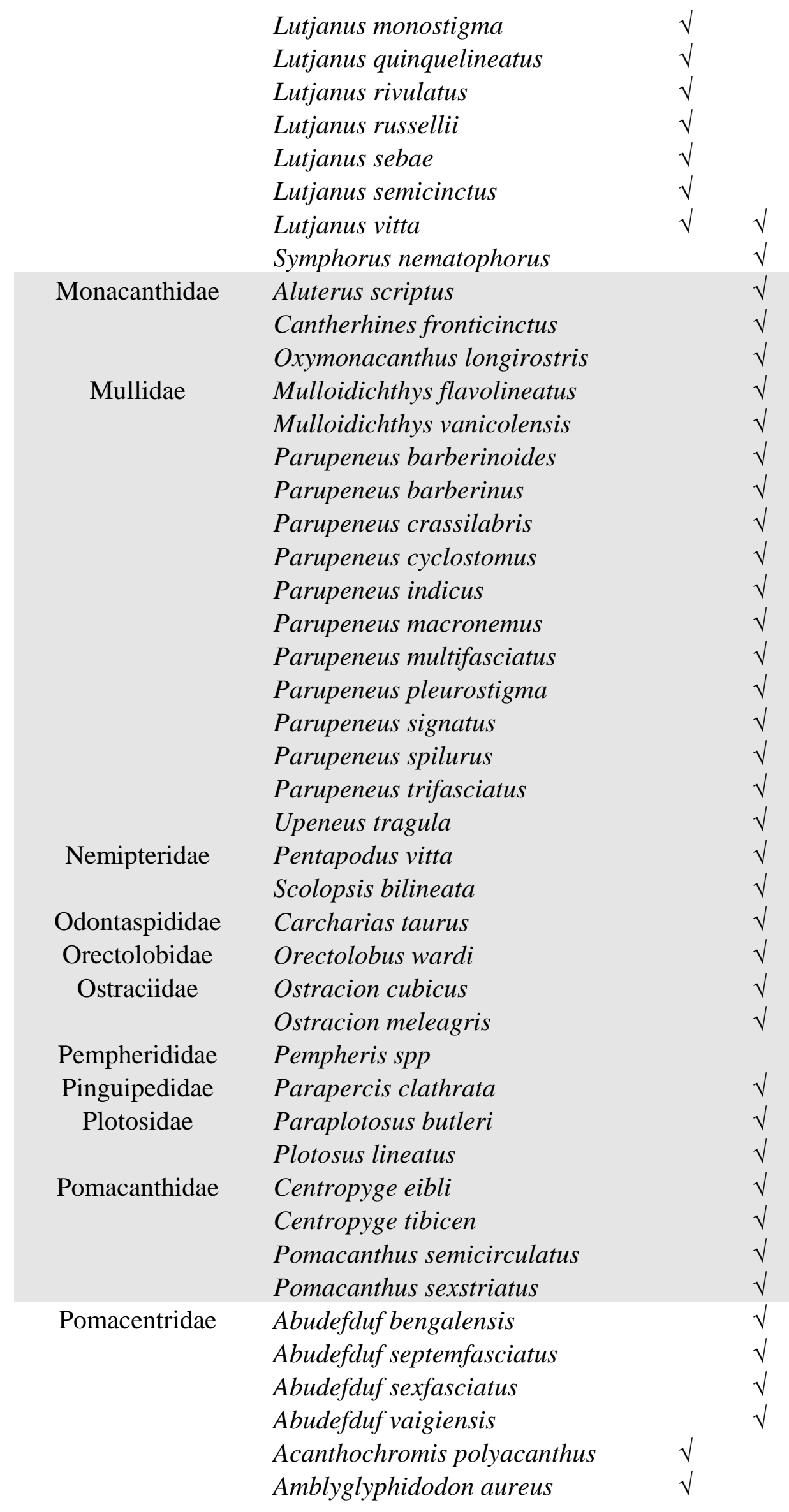


Amblyglyphidodon curacao Amblyglyphidodon leucogaster Amphiprion akindynos Amphiprion chrysopterus Amphiprion clarkii Amphiprion melanopus Amphiprion percula Amphiprion perideraion Amphiprion rubrocinctus Cheiloprion labiatus Chromis acares Chromis agilis Chromis amboinensis Chromis atripectoralis Chromis atripes Chromis chrysura Chromis cinerascens Chromis flavomaculata Chromis iomelas Chromis lepidolepis Chromis lineata Chromis margaritifer Chromis nitida Chromis retrofasciata Chromis ternatensis Chromis vanderbilti Chromis viridis Chromis weberi Chromis xanthochira Chromis xanthura Chrysiptera biocellata Chrysiptera flavipinnis Chrysiptera hemicyanea Chrysiptera rex Chrysiptera rollandi Chrysiptera talboti Dascyllus aruanus Dascyllus aruanus Dascyllus melanurus Dascyllus reticulatus Dascyllus trimaculatus Dischistodus melanotus Dischistodus perspicillatus Dischistodus prosopotaenia Dischistodus 


\begin{tabular}{|c|c|c|c|}
\hline & pseudochrysopoecilus & & \\
\hline & Hemiglyphidodon plagiometopon & $\sqrt{ }$ & $\sqrt{ }$ \\
\hline & Neoglyphidodon melas & $\sqrt{ }$ & $\sqrt{ }$ \\
\hline & Neoglyphidodon nigroris & $\sqrt{ }$ & $\sqrt{ }$ \\
\hline & Neoglyphidodon polyacanthus & $\sqrt{ }$ & \\
\hline & Neopomacentrus azysron & $\sqrt{ }$ & \\
\hline & Neopomacentrus bankieri & $\sqrt{ }$ & \\
\hline & Neopomacentrus cyanomos & $\sqrt{ }$ & \\
\hline & Neopomacentrus filamentosus & & $\sqrt{ }$ \\
\hline & Plectroglyphididon lacrymatus & & $\sqrt{ }$ \\
\hline & Plectroglyphidodon dickii & $\sqrt{ }$ & $\sqrt{ }$ \\
\hline & Plectroglyphidodon & & \\
\hline & johnstonianus & $\sqrt{ }$ & $\sqrt{ }$ \\
\hline & Plectroglyphidodon lacrymatus & $\sqrt{ }$ & $\sqrt{ }$ \\
\hline & Plectroglyphidodon leucozonus & & $\sqrt{ }$ \\
\hline & Pomacentrus adelus & $\sqrt{ }$ & $\sqrt{ }$ \\
\hline & Pomacentrus alexanderae & & $\sqrt{ }$ \\
\hline & Pomacentrus amboinensis & $\sqrt{ }$ & $\sqrt{ }$ \\
\hline & Pomacentrus australis & $\sqrt{ }$ & \\
\hline & Pomacentrus bankanensis & $\sqrt{ }$ & \\
\hline & Pomacentrus brachialis & $\sqrt{ }$ & \\
\hline & Pomacentrus chrysurus & $\sqrt{ }$ & \\
\hline & Pomacentrus coelestis & $\sqrt{ }$ & $\sqrt{ }$ \\
\hline & Pomacentrus grammorhynchus & $\sqrt{ }$ & \\
\hline & Pomacentrus imitator & $\sqrt{ }$ & \\
\hline & Pomacentrus lepidogenys & $\sqrt{ }$ & \\
\hline & Pomacentrus moluccensis & $\sqrt{ }$ & \\
\hline & Pomacentrus nagasakiensis & $\sqrt{ }$ & \\
\hline & Pomacentrus nigromarginatus & $\sqrt{ }$ & \\
\hline & Pomacentrus philippinus & $\sqrt{ }$ & \\
\hline & Pomacentrus vaiuli & $\sqrt{ }$ & $\sqrt{ }$ \\
\hline & Pomacentrus wardi & $\sqrt{ }$ & \\
\hline & Pomachromis richardsoni & $\sqrt{ }$ & \\
\hline & Premnas biaculeatus & $\sqrt{ }$ & \\
\hline & Stegastes apicalis & $\sqrt{ }$ & \\
\hline & Stegastes fasciolatus & $\sqrt{ }$ & $\sqrt{ }$ \\
\hline & Stegastes gascoynei & $\sqrt{ }$ & \\
\hline & Stegastes nigricans & $\sqrt{ }$ & $\sqrt{ }$ \\
\hline Pseudochromidae & Labracinus lineatus & & $\sqrt{ }$ \\
\hline & Pseudochromis fuscus & & $\sqrt{ }$ \\
\hline Rachycentridae & Rachycentron canadum & & $\sqrt{ }$ \\
\hline Scaridae & Bolbometopon muricatum & $\sqrt{ }$ & \\
\hline & Calotomus carolinus & $\sqrt{ }$ & \\
\hline & Cetoscarus bicolor & $\sqrt{ }$ & \\
\hline & Chlorurus bleekeri & $\sqrt{ }$ & \\
\hline
\end{tabular}


Chlorurus frontalis

Chlorurus japanensis

Chlorurus microrhinos

Chlorurus schlegeli

Chlorurus sordidus

Hipposcarus longiceps

Leptoscarus vaigiensis

Scarus altipinnis

Scarus chameleon

Scarus dimidiatus

Scarus flavipectoralis

Scarus forsteni

Scarus frenatus

Scarus ghobban

Scarus globiceps

Scarus longipinnis

Scarus niger

Scarus oviceps

Scarus prasiognathos

Scarus psittacus

Scarus quoyi

Scarus rivulatus

Scarus rubroviolaceus

Scarus schlegeli

Scarus spinus

Scorpaenidae

Pterois volitans

Serranidae

Cephalopholis argus

Cephalopholis miniata

Cromileptes altivelis

Epinephelus bilobatus

Epinephelus polyphekadion

Epinephelus rivulatus

Plectropomus areolatus

Plectropomus laevis

Plectropomus leopardus

Plectropomus maculatus

Variola albimarginata

Variola louti

Siganidae

Siganus argenteus

Siganus canaliculatus

Siganus corallinus

Siganus doliatus

Siganus fuscescens

Siganus guttatus

Siganus javus 
Siganus lineatus

Siganus nebulosus

Siganus puellus

Siganus punctatissimus

Siganus punctatus

Siganus spinus

Siganus trispilos

Siganus virgatus

Siganus vulpinus

Sphyraenidae Sphyraena jello

Synodontidae Saurida gracilis

Tetraodontidae Arothron hispidus

Arothron stellatus

Canthigaster coronata

Canthigaster rivulata

Zanclidae

Canthigaster valentini

Zanclus cornutus

690 